\title{
KRISTOLOGI KETUHANAN YESUS PADA ISU SLAVERY GAYA BARU: SUATU USAHA KONTEKSTUALISASI INJILI
}

\author{
Togardo Siburian
}

\begin{abstract}
Abstrak
Tulisan ini adalah refleksi kontemporer atas doktrin ketuhanan Yesus pada situasi perbudakan gaya baru dewasa ini. Studi doktrinal Injili selama ini mengalami kemandegan dogmatisme, karena hanya pengulangan tema-tema abstrak tanpa terkait dengan kehidupan riil. Khususnya dalam pengaplikasian kristologi ketuhanan Yesus pada konteks segar, di mana kekristenan berada. Refleksi Injili sekarang terlalu menekankan kristologi "from above"dalam tema keilahian-Nya seperti: supremasi, keunikan, dan finalitas Kristus, tetapi melalaikan perspektif "from afore" pada dampak penebusan Kristus dalam kehidupan Kristen secara aktual. Kecenderungan hasilnya adalah pemisahan kejuruselamatan dari ketuhanan-Nya sampai pada pemisahan pengakuan dan praktik ketuhanan Yesus. Pada kondisi ini, tulisan aplikatif kontekstual Kristologi Injili hanya konsep superiorisme Kristus di atas oknum dan melawan isu-isu ideologis di sekitar kegerejaan masa kini. Di sini pentingnya reformulasi Kristologi Injili yang seimbang antara tematema keilahian dan isu kemanusiaan yang berfokus pada ketuhanan dan kejuruselamatan-Nya, keprihatinan apologetis dengan etis, kepercayaan konseptual dengan praktika, juga implementasi kristologis Injili yang parenialisme dalam kontekstualisme. Lalu mereartikulasikan ketuhanan Yesus yang teraplikasi dalam isu-isu kemanusiaan sekarang, berdasarkan hubunganhubungan komprehensif tema ketuhanan-Nya. Pada konteks ini ada kesempatan bagi kaum Injili untuk mengkontekstualisasikan doktrin Kristus (Kristologi) pada soal khusus, seperti perbudakan masa kini yang muncul lagi dalam gaya baru.
\end{abstract}




\section{Pendahuluan}

Kebanyakan teologi Injili berputar-putar pada tema-tema, seperti finalitas Kristus, superiorisme Kristus, ketuhanan Kristus pra eksistensi-inkarnasi, eksklusivisme, dll. Seharusnya bagi kaum Injili konsep dasar ini sudah selesai. Namun sampai sekarang hal ini terus diulang-ulang pada pembicaraan yang sama persis. Sekarang bagaimana konsep Christus Victor tersebut direfleksikan kembali dalam kondisi tanggungjawab teologis gereja di tengah dunia? Dulu prinsip "Christus victor"1 sangat agung dengan bahasan utama pada tema atonement yang terkait dengan status kejuruselamatan Kristus yang unik sebagai bentuk penjelasan apologetis terhadap zamannya. Sebenarnya ini adalah tipikal utama penjelasan Kristologi Injili sejak awal kekristenan sampai era pertengahan dan reformasi, bahkan sampai sekarang. Tema "Kristus Pemenang" yang semula adalah suatu pengagungan atas penebusan Kristus, kini telah menjadi superiorisme Kristus atas ideologi-ideologi di sekitar gereja dan oknum masa kini yang muncul di dalam gereja. Ekstrimnya, ini menjadi superiorisme dan eksklusivisme agama Kristen demi memerangi isu pluralisme ekstrim. Memang prinsip finalitas dan kemutlakan Kristus adalah pengakuan Injili, tetapi penggunaannya tidak terlalu produktif (bahkan menjadi kontraproduktif) dalam dinamika intelektual studi Kristologi pada gereja di dunia ini.

Mungkin ini saatnya kaum Injili satu langkah lebih maju dalam studi Kristologi melalui doktrin ketuhanan Yesus pada konteks permasalahan dunia dan kemanusiaan dewasa ini. Ini adalah pintu bagi kaum Injili dapat berefleksi teologis, “Apakah artinya menerima Yesus secara pribadi di dalam dirinya sebagai Tuhan kalau tidak melihat dan menerapkannya dalam perjuangan memanusiakan manusia di bawah ketuhanan Yesus?” Di sini ada kesempatan untuk merefleksikan Kristologi kontemporer, khususnya tema Ketuhanan (lordship) Yesus dalam isu kemanusiaan yang berfokus pada situasi perbudakan gaya baru di era ini. Pengakuan akan ketuhanan Yesus di dunia ini harus dapat direartikulasi secara konteks riil, karena

\footnotetext{
${ }^{1}$ Misalnya melihat buku klasik Gustaf Aulien, Christus Victor: Historical Study of The Three Main Types of the Idea of Atonement (New York: McMillan Co., 1972 [1969]).
} 
suatu refleksi Kristologis Injili tidak hanya pemikiran parenalisme di awang-awang, tetapi juga dalam konteks riil dan aktual orang yang mempercayai pribadi dan karya Kristus.

\section{Kondisi Studi Kristologi Injili Dewasa Ini}

\section{Kemandegan Kristologi Injili (Khususnya Non Barat)}

Di sini yang dimaksud jalan di tempat adalah mandeg, meskipun tetap bergerak menuju jalan buntu. Kristologi Injili yang dipelajari selama ini terlalu abstrak dalam konsep sorgawi yang berputar-putar. Ini agak sia-sia dalam pengulangan: istilah, tokoh, dan tema teologi masa lalu. Tema-temanya adalah peninggalan kekristenan Barat abad pertengahan sampai modern yang bahan-bahannya tidak langsung terkait lagi dengan pergumulan gereja masa sekarang. Sebenarnya kondisi dan situasi berteologi di Barat pun sudah berubah drastis di era pascamodern ini.

Setidaknya studi Kristologi Injili dewasa ini menggunakan 'peta baru' dengan isu-isu kekiniannya, agar berita dan pengajaran Kristen ada relevansinya bagi pergumulan Kristen. Namun faktanya, Kristologi Injili dewasa ini seakan-akan masih hidup di abad lalu dengan "peta usang" yang berbeda sama sekali dengan realitas masakini. Bahkan sudah tidak ada lagi di peta kehidupan sekarang. Apalagi sejak dulu ada kesenjangan konteks kultur historis dan geopolitik orang Asia dari orang Barat. Di sini pelajar Injili harus bergerak maju, kecuali jika hanya ingin berbangga dalam pengulangan materi lama tanpa konteks berpikir yang riil.

Ini disebabkan bukan hanya soal kondisi "ketidakmelekan teologis" (masalah buta-huruf teologi) atau soal tidak adanya pengetahuan teologi. Namun sejauh ini adalah sikap 'kemasabodohan' Injili dan ketidakmampuan berpikir teologis secara dinamis dan kritis, dikarenakan sikap dogmatisme dan tindakan indoktrinasi sempit. ${ }^{2}$ Setiap kajian teologi yang benar tidak bisa dalam ruang kosong, meskipun ada juga

2 Togardo Siburian, "Kemelekan Teologis Dan Penulisan Injili” Geneva: Jurnal Teologi dan Misi, Vol. 1 No. 1 (Agustus 2011): 133-153. 
ruang berisi yang "khayal," yaitu ide persaingan agama sebagai sisa-sisa misi orientalisme masa lalu yang sebenarnya dapat dikatakan sebagai "ruang kosong," karena sengaja menghindar dari problem kerusakan peradaban yang dikonsekuensikan oleh kajian demikian.

Beberapa dosen Injili secara tajam menolak usaha kontekstualisasi teologi untuk masa kini dan menyerang idenya secara membabi-buta sebagai “kesesatan.” Padahal, Komisi Teologi WEF di Manila, 1989 sudah melihat keunikan Kristus secara lebih luas dalam permasalahan agama-agama yang pluralistik, bahkan sampai pada pembicaraan mengenai keadilan manusia dan kedamaian dunia. ${ }^{3}$ Memang Kristologi Injili sangat tegas akan tema 'keutamaan Kristus' yang berimbas pada "the uniqueness of Christ has to be derived from, the Bible, without which we do not have any theological basis for presenting Jesus Christ as Lord and Savior of the world. Furthermore, we should lack any basis for addressing issues of peace and justice" berdasarkan kepercayaan "Christ can't offer to the world his salvation, peace and justice if he himself does not have not have any universal value and import." Karena itu, "his lordship authority and supremacy are intrinsic to him ... so our responsibility therefore, is only to recognize, believe, confess and proclaim him." Semua itu adalah pembahasan penting dalam deklarasi bagian III tentang "challenge of modernity” poin (B) mengenai “modernity’s harm.”

The engine of economic growth that has raised the standard of living for many hundreds million of people has also left many other people in poverty and hunger, forcing them to sell their labour for wages than can't sustain life, to sell their daughters into proposition and to sell or abandon their traditional lands and home. ${ }^{5}$

Seorang misiologis Injili sempat melihat betapa pentingnya konsep lordship of Christ dalam isu-isu realistik dunia ini, ${ }^{6}$ walaupun belum sempat melihat frase lain, godship atau lordness of Jesus. Selama ini kaum Injili menganggapnya sama saja dalam substansinya, karena keduanya memang tidak terpisahkan

\footnotetext{
${ }^{3}$ Bruce Nicholls, The Unique Christ in Our Pluralist World (Carlisle, Grand Rapids Paternoster: Baker Books, 1994). Secara khusus bagian lima tentang Unique Christ for Peace and Justice, 167-230.

${ }^{4}$ Bagian lima menuliskan 4 artikel mengenai tema "The Unique Christ for Peace and Justice”, 183. Secara keseluruhan buku ini adalah refleksi khusus atas deklarasi WEF di Manila, yang menghasilkan 3 bagian besar deklarasi mengenai Kristus terkait kenyataan masa kini: 1) pluralitas agama, 2) tantangan modernitas dunia dan keunikan Kristus menghadapi ideologi politis dunia, 3) masalah kemajemukan gereja dengan Kristus sebagai harapan penghakiman dunia.

${ }^{5}$ Nicholls, The Unique, 17.

${ }^{6}$ Nicholls, The Unique, 17.
} 
dalam pribadi Yesus Kristus. Namun secara tujuan dan penjelasan teologis agak berbeda, sehingga ada jalan pemikiran lanjutan bahwa prinsip lordness Jesus (godship dan divinity of Christ) harus dilampaui menuju lordship Jesus, setelah kebangkitan dan pemerintahan-Nya dengan segala kuasa atas orang percaya dan seluruh dunia sampai Dia datang kembali.

Selain itu, teolog Injili dapat belajar dari teolog ekumenis untuk memikirkan kembali ironi pernyataan iman dan praktik berteologinya yang tidak konsisten selama ini. Seperti yang pernah Choan-Seng Song sindir sebagai "keluguan teologi," secara khusus pada "mereka yang menyebut dirinya evangelikal..., khususnya di dunia ketiga," ketika beliau mengutip deklarasi misi Injili yang berkomitmen kristologis pada isu-isu kemanusiaan sekarang, seperti tertera di bawah ini:

\footnotetext{
"Kami menyatakan solidaritas kemanusiaan bersama orang-orang miskin, mereka yang tak berdaya, tertindas di seluruh dunia, mereka yang memeluk agama-agama lain, dan dengan semua orang di mana-mana. Kami mengakui bahwa kita semua diciptakan sesuai dengan Gambar Allah, namun kita kehilangan kemuliaanNya, Kristus datang, hidup, mati dan bangkit kembali bagi kita semua. Kita semua berada di bawah kedaulatan Tuhan Yesus Kristus. Kami mempunyai komitmen untuk memberitakan-Nya kepada semua orang, khususnya saudara-saudara dan saudari-saudari kami di dunia dua pertiga." 8
}

Keprihatinannya adalah “apakah mungkin karena komitmen-komitmen deklaratif para 'elit' Injili dunia itu tidak tertangkap oleh arus bawah Injili, khususnya pelajar Asia? Sehingga kebanyakan teologinya berputar-putar di situ saja, khususnya hanya mempertajam rumusan kristologis Barat tentang supremasi Kristus. Atau kemungkinan besar kristologis Injili alergi untuk melebarkan fokus secara situasional, karena dianggap sebagai sinkritisme dan sesat. Hal ini karena "pendekatan kenabian" dicap liberal, dan metodenya yang "mencari kebenaran" selalu diperlawankan dengan pendekatan "kerasulan," serta diklaim ortodoks karena metodenya "mengajarkan kebenaran." Padahal semua pendekatan itu bersifat alkitabiah dan dapat

\footnotetext{
${ }^{7}$ Lih. Choan-Seng Song, Yesus dan Pemerintahan Allah, terj. (Jakarta: BPK Gunung Mulia, 2010). Ini suatu jenis kristologi kontekstual yang melihat situasi era ini di Asia dan tidak hanya teologi Barat.

${ }^{8}$ Song, 321 Beliau mengambil dari Vinay Samuel dan Chris Sugden, eds., Sharing Jesus in Two-Third: Evangelical Christology from Context of Poverty Powerless and Religious Pluralism (Grand Rapids: Wm Eerdmans Pub. 1883), 279.

${ }^{9}$ Saya kira ini khususnya pengaruh generalisasi sepintas kaum Injili atas pengkategorian lama dari Bong Ring Ro tentang pendekatan situasional, pendekatan kenabian dalam The Bible \& Theology in Asian Context, Bong- Ring Ro, Ruth Eshahaur, eds.
} 
digunakan secara proporsional dalam suatu kegiatan berpikir teologis yang komprehensif. Selama ini, pelajar Injili selalu ditakut-takuti dengan kesesatan doktrin, lalu enggan melihat masalah-masalah sosial karena dianggap liberal dan terlalu duniawi.

Sebenarnya teologi yang konservatif tidak harus menolak aspek holistik dari sifat misional gereja. karena situasi dan realitas hidup sebagai kenyataan teologis yang tak terbantahkan. Setiap rumusan teologis apapun bersifat situasional sebagai konteks pergumulan. Hal ini mengingat berteologi dari dalam dirinya adalah dinamis dan selalu merefleksi segar atas situasi dan kondisi yang berkembang, di mana orang Kristen dan gereja berada dalam menyembah Kristus. Pengertian doktrin bukanlah dogma semata, layaknya studi teologi sistematika tidak identik dengan dogmatika. Jika Kristologi Injili hanya mengulang-ulang konsep abstrak sebagai produk masa lalu yang dipaksakan untuk dipelajari, maka itu menyangkali hakikat studinya sendiri. Teologi harus dapat keluar dari ruang 'antah-berantah,' sehingga setiap pemikirannya selalu ada konteks riilnya di dalam segala masa yang berkembang. Suatu usaha teologis Injili harus menggunakan 'peta teologis' yang segar, kecuali kalau hanya belajar teologi fosil, sebagai pajangan agama.

Teologi Injili menekankan Kristologi "dari atas" dan mengabaikan Kristologi “dari depan,” yaitu pengaruh-pengaruh Kristus dalam orang percaya masa kini. Sebenarnya prinsip inkarnasi sekaligus kenaikan-Nya sebagai Tuhan atas dunia sangat penting untuk meneruskan implementasi keutamaan Kristus pada isu-isu riil kehidupan orang percaya sekarang. Pengingatan bagi murid-murid Injili bahwa tidak boleh lagi hanya menggembar-gemborkan "dua natur Kristus" dalam Allah-Manusia sejati (seratus persen), karena itu sudah menjadi aksioma Injili. Di sini kaum Injili seharusnya sudah menyelesaikan persoalan dilematis itu dan melampauinya tanpa meninggalkan ortodoksinya.

Faktanya, doktrin Injili selama ini terlalu menekankan Yesus sebagai Juruselamat atas orang percaya dari segi rohani internal, sehingga sering mengabaikan peran ketuhanan Yesus atas dunia ini, khususnya pada masalah-masalah eksternal Kristen. Bahkan diduga keterlibatan Injili dalam masyarakat sangat diragukan oleh kaum Injili itu sendiri sebagai sikap dualisme hidup. Di mana kehidupan rohaniah 
dikontraskan dengan kehidupan jasmaniah, dunia sakral versus dunia profane dengan segala permasalahan sosial dunia. Ini menghasilkan doktrin tentang Kristus yang tidak lengkap untuk kehidupan Kristen. Inilah saatnya memanggil jiwa doktrinal Injili untuk berkristologi yang lebih komplit dan holistik dalam implementasi doktrin-doktrin pada kehidupan aktual. Secara prinsipil, kehidupan Kristen bersifat tunggal dalam tugas total Kerajaan Allah dan berpola pada prinsip inkarnasi Kristus.

Hal itu harus menjadi motif misional dalam pengimplementasian konsep Christus Victor selama ini, kedalam kondisi tanggungjawab teologis gereja di tengah dunia. Teologi Injili harus menolak dogmatisme sempit yang menghindarkan iman partikularnya dari kehidupan publik. Selama ini kaum Injili lebih banyak mengembangkan tema keunggulan Kristus dalam prinsip superiorisme Kristus terhadap 'yang lain' berdasarkan simbol-simbol agama. Alhasil, semua pesan inti konsep keutamaan dan keunikan Kristus bagi orang beriman di dunia ini hanya sampai pada superiorisme Kristus dan eksklusivisme agama Kristen di tengah pluralisme agama. Jadi makna keutamaan (supremasi) Kristus sebagai Pemenang hanya teraplikasi dalam soteriologi sempit yang memisahkan keselamatan rohani dari keprihatinan sosial Kerajaan Allah. Pesan sebenarnya dari tema keutamaan-Nya, yaitu prinsip partikularisme iman berdasarkan kelahiran baru. Dalam batas-batas iman personal (bukan privat) inilah, Kristen dapat hidup toleran di dalam ranah publik yang pluralistik.

Selanjutnya pada masa kini dikembangkan prinsip keunikan Kristus, karena masih terus menghadapi pendekatan pluralisme agama yang ekstrim, dalam tema-tema aplikatif dari tema: lordship, authority and supremacy of Christ dan disambung dengan pernyataan, bahwa "Jesus Christ as only the Lord of the world." ${ }^{10}$ Itu pernyataan bagus keunikan Kristus. Sayangnya sering dipakai hanya menunjukkan kembali prinsip superiorisme Kristus terhadap dunia ini. Sehingga menjadi kontraproduktif dan gagal menarik implikasinya pada isu-isu kemanusiaan modern di sekeliling gereja. Akhirnya, kaum Injili tidak berhasil menelurkan Kristologi yang segar dalam konteks kekinian dunia dari tema-tema supremasi dan otoritas

\footnotetext{
${ }^{10}$ Ro, The Bible \& Theology, 184 dst.
} 
Kristus. Sebaliknya justru terjatuh ke dalam keunggulan agama Kristen terhadap "yang lain" ${ }^{11}$ dalam teknik persaingan agama yang didalihkan sebagai tugas apologetis yang bersifat perbantahan agama. Tujuan akhir dari tema-tema superiorisme itu bukanlah melihat keutamaan Kristus lagi, tetapi 'mengadu' Kristus melawan para pendiri agama-agama lain, dengan cara mempopulerkan topik ekstrim “eksklusivisme agama” diluar kewajaran, khususnya dalam kancah persaingan agama demi populasi.

Apalagi para misiolog Injili sangat jelas melihat isu-isu global, seperti dalam Konsensus Laussane, dari pertama sampai ketiga,.misalnya, komitmen misi Injili dalam Lausanne II Manila yang berslogan: "Whole Gospel, Whole Church and Whole World" yang dikenal popular dengan sebutan "misi holistik" sebagai pengembangan dan penjabaran dari poin 5 pada Perjanjian Lausanne '74 mengenai "Evangelism and Social Concern." Pada awal abad $21 \mathrm{M}$, komitmen tersebut diperbaharui oleh Lausanne III dalam rumusan aksi Capetown Commitment yang secara lugas menyebutkan "slavery" bergandengan dengan istilah "human trafficking.”

There are more people all around the world in slavery today (an estimated 27 million) than 200 years ago when Wilberforce fought to abolish the transatlantic slave trade. In India alone there are an estimated 15 million bonded children. The caste system oppresses low caste groups and excludes Dalits. But sadly the Christian Church itself is infected in many places with the same forms of discrimination. The concerted voice of the global Church must be raised in protest against what is in effect one of the world's oldest systems of slavery. But if such global advocacy is to have any authenticity, the Church must reject all inequality and discrimination within itself.... Migration on an unprecedented scale in today's world, for a variety of reasons, has led to human trafficking on every continent, the widespread enslavement of women and children in the sex trade, and the abuse of children through enforced labour or military conscription. ${ }^{12}$

Sebenarnya hal-hal kemanusiaan di atas menjadi menarik dalam misi Injili, karena sengaja dikaitkan di bawah tema kepercayaan akan supremasi Kristus, dan sekaligus memanggil kaum Injili secara serius untuk

${ }^{11}$ Ajith Fernando, Supremasi Kristus, terj. (Surabaya: Momentum, 2006), 3-13. Maksudnya supremasi atau keutamaam Kristus yang sebenarnya didasarkan pada Kolose 1:13, telah diubah makna dan pembahasannya menjadi superiorisme Kristus, khususnya situasi pluralisme agama-agama.

$12 \mathrm{https}: / /$ www.lausanne.org/content/ctc/ctcommitment\#p2-2 di akses lagi 1 Desember 2016. PART II For the world we serve: The Cape Town Call to Action bagian B mengenai "Building the peace of Christ in our divided and broken world" dan secara konkrit pada poin 3 diakui adanya masalah mengenai kemanusiaan dalam poin Christ's peace for the poor and oppressed. 
memikirkan Kristologi lebih luas lagi dalam usaha merumuskan doktrin yang lebih implementatif dan aplikatif pada situasi peradaban sekarang. Kondisi di atas adalah misi kristologis atau kristologi misional bagi teologi Injili sekarang. Kristolog Injili harus tetap mengingat bahwa prinsip pewahyuan proposisional melalui proses inspirasi organik Alkitab pun ada konteks historisnya juga.

Jadi untuk menghadapi jalan buntu dan kemandegan Kristologi ini, kaum Injili harus mengindahi konteks kekinian yang dinamis dan fresh di sekitar kehidupan gereja. Walaupun Injili tidak dapat menghindari pentingnya studi sejarah teologis dari konteks masa lampaunya, namun tidak boleh berhenti sampai di sana.

\section{Melihat Dinamika Teologi Injili Barat Selama Ini}

Di Barat, kaum Injili yang lebih mapan telah melihat 'sandungan' dalam teologinya, dengan pernyataan "there is theological dimensions to scandal of evangelical mind, for an entire christian community to neglect, - generation after generation - serious attention to the mind, nature, society, the arts - all spheres created by God." ${ }^{13}$ Ini suatu keprihatinan teologis terkait dengan sikap anti intelektualisme dalam pemikiran Injili selama ini ${ }^{14}$ termasuk juga Kristologi. Di dunia Barat, golongan Injili utama menolak spirit rasionalisme modernis sekaligus melawan sikap anti intelektualisme fundamentalis, karena Pribadi dan karya Kristus penuh dengan hal-hal iman yang supra-rasional, seperti tema-tema Injili yang sudah tidak tergugat lagi dalam keunikan Kristus: keilahian Yesus dalam pra eksistensi-Nya, dua natur Kristus dalam inkarnasi-Nya, ketanpadosaan Kristus, prinsip Penebusan-Pengganti, janji kemesiasan pra inkarnasi, sampai pada tema supremasi ketuhanan dan kejuruselamatan-Nya. ${ }^{15}$ Namun demikian kaum Injili menekankan pentingnya Kristologi 'dari atas,' 'dari belakang,' 'dari bawah,' bahkan 'dari depan,' khususnya melihat

${ }^{13}$ Mark A Noll, Scandal of The Evangelical Mind (Grand Rapids, Leicester: Wm Eerdmans, Intervarsity, 1994), 23. Dia membagi tiga elemen yang menyandung pemikiran Injili yang saya kira masih berlanjut sampai sekarang ini "cultural, institutional, theological (12 dst). Beliau melihat ini sebagai suatu "maybe, in fact, sinful" karena hanya untuk "sustained for his own glory".

${ }^{14}$ Noll, Scandal of, 23.

${ }^{15}$ John Stott, Kristus yang Tiada Tara, terj, (Surabaya: Momentum 2007). Seperti Kristologi sorgawi "perspektif dari atas) Penebus, Mulia, Unik, dalam pra eksistensi dan pra inkarnasi, Allah sejati manusia sejati, termasuk teladan moral ilahi, Gambar Guru Mulia ilahi berdasarkan Alkitab (9-70). Semuanya ini sudah jelas dan tidak masalah lagi bagi kaum Injili, termasuk pengaruhpengaruhnya dalam tema lanjutan. Penjelasan Kristen secara dinamis di sepanjang masa dan segala tempat sedang mengerjakan doktrin Kristus yang mungkin hanya parenialisme bagi kita sekarang (dapat di lihat 75-167). 
dampak Kristologi ketuhanan Yesus dalam konteks dinamis yang berkembang. Gereja-gereja sebagai agen perubahan sosial, khususnya dari tema ketuhanan Yesus yang bangkit dan naik ke sorga serta yang akan datang lagi sebagai "Tuhan yang menghakimi." Aksioma Injili, Tuhan Yesus yang berinkarnasi ini telah menanggulangi masalah terbesar, yaitu dengan memerdekakan manusia dari kutuk maut dosa.

Selanjutnya Kristologi kontemporer harus diartikan sebagai pemikiran lanjutan dalam doktrinal yang teraplikasi pada pergumulan aktual manusia, seperti munculnya isu perbudakan jenis baru di tengah-tengah dunia sekarang. Di sini perlu dicatat frase Wells, "di atas tetapi berinkarnasi" dan "di atas dan sedang memerintah." ${ }^{16}$ Kedua hal itu kemungkinan dapat dijadikan pintu masuk yang sangat lebar untuk berkristologi dalam konteks pergumulan manusia dan dunia, di mana Gereja berada di era ini. Jadi berdasarkan pola dan motif inkarnasi-Nya, bagaimana rahmat keselamatan Yesus perlu dipikirkan lagi berdasarkan pemerintahan Allah di dalam hati kita secara moral dan nurani, sebagai Tuhan yang sedang memerintah dari atas, dan melalui Injil Kerajaan Allah dalam pemberitaan gereja dalam hal keselamatan dan kerohanian, sekaligus juga melawan kejahatan, ketidakadilan, menolong orang yang tertindas, dan lainlain. Walau Wells sudah berniat menerobos sampai ke sana, namun belum terlihat dalam pemikiran kristologinya secara jelas pada situasi kemanusiaan sekarang. Walau diakui bahwa sudah ada pembicaraan tentang budaya pop dan keagamaan di sekeliling Kristen, tetapi belum terlihat merambah sampai pada isu-isu spesifik menangani situasi kekinian, seperti: perbudakan, lingkungan hidup, diskriminasi ras, kemiskinan dalam dunia ini. Beliau memang sudah bereaksi terhadap masalah-masalah gereja-gereja Injili akibat sekularisasi budaya pop seperti: gerakan seeker sensitive dan emergent church, manajemen transaksional, pasar bagi boomer, mega church yang pragmatis sampai pada relativisasi Kristus, di dalam istilah "kekristenan yang diobral."17 Memang ada benarnya, jika kaum Injili sekarang dirasakan telah mengkhianati gerakan doktrinalnya, karena menganggapnya sebagai suatu ketumpulan praktik iman dan hanya memecah belah Kristen.

\footnotetext{
${ }^{16}$ Melihat dari judul buku David F. Wells, Mengatasi Segala Kuasa Dunia: Kristus di Dalam Era Pascamodern, terj. (Surabaya: Momentum, 2015), kita tahu ini adalah tipikal tema Kristologi Injili yang teraplikasi pada isu masa kini dan mengindikasikan superiorisme Kristus.

${ }^{17}$ Wells, Mengatasi Segala, 310 dst.
} 
Doktrin Injili tentang Yesus sebagai Tuhan dan Juruselamat yang berkaitan dengan keselamatan partikular dalam prinsip lahir baru, tentu berbeda dari non Injili yang hanya menerima secara dogmatis akan ketuhanan Yesus tanpa komitmen pada keunikan-Nya dalam keselamatan. Ada ketimpangan antara pengakuan Injili dengan praktik. Di mana Kristus yang diakui sebagai Tuhan di Sorga dan di hati, namun banyak yang tidak memperlakukan Dia selayaknya Tuhan dalam kehidupan praktis, pemikiran, dan pengajaran teologisnya, bahkan mengabaikan eksistensi orang lain yang dianggap lebih rendah, layaknya hubungan superior-inferior. Di sini pemikiran John Stott sangat tepat ketika melihat ketidakpedulian Kristen (Injili) pada masalah-masalah sosial manusia, dikarenakan 'doktrin-doktrin yang tidak genap' termasuk doktrin tentang Kristus. ${ }^{18}$ Menurutnya, fokusnya tidak terkait sama sekali dengan dunia nyata dalam pemisahan "kejuruselamatan" dari "ketuhanan" Yesus dan memisahkan makna keselamatan Kristen dari Kerajaan Allah. ${ }^{19}$ Artinya pemikiran kristologisnya abstrak, karena tidak terkait dengan dunia nyata.

Donald G. Bloesch melihat kontroversi ketuhanan Kristus di sekitar relasi antara "the natural Lordship of Christ and his redeeming Lordship" atau dengan kata lain dapat dipertanyakan, "Apakah ketuhanan Yesus atas manusia berdasarkan hanya penciptaan atau juga dengan penebusan?" dengan lain kalimat, "Apakah penebusan-Nya terbatas pada komunitas orang percaya" [atau juga]... di luar sejarah atau tidak masuk sejarah? Atau "Kerajaan Kristus terealisir di luar atau di dalam lapisan iman?"20 Ternyata ini adalah pertanyaan-pertanyaan yang masih diperdebatkan di antara orang Injili, khususnya pada kondisi problem aktual manusia. Jadi Kristologi Injili harus juga menyoroti tema ketuhanan Yesus dengan relasi penebusanNya secara spiritual atau relasi kekristenan dalam komunitas iman dan seluruh dunia. Ini adalah jalan masuk untuk mengurusi dunia dari perspektif ketuhanan, setelah kebangkitan-Nya.

Belajar dari ceramah lama Abraham Kuyper mengenai "Yesus Kristus dan problema sosial" sampai sekarang masih berlaku dalam gerakan Injili, bahwa "Yesus lebih dari sekedar pembaharu sosial" dan sebagai sang Juruselamat. "Kristus sendiri senantiasa lebih menekankan pentingnya kesejahteraan kekal

\footnotetext{
18 John Stott. Isu-isu Global Menantang Kepemimpinan Kristen, terj. (Jakarta: OMF/YKBKB, 1992), 14,15. Apakah itu dalam studi teologi proper, kristologi, soteriologi, eklesiologi, dan antropologi.

${ }^{19}$ Stott. Isu-isu, 16,17. Ia sendiri mengakui bahwa "orang Kristen lahir baru" cenderung abstain, karena pandangan mereka suram tentang manusia... dan membandingkannya secara eksplisit dengan "Kristen liberal" (47).

${ }^{20}$ Donald G. Bloesch, Jesus Christ: Savior and Lord (Downers Grove: InterVarsity, 1997), 211.
} 
manusia" walaupun " berkat-berkat yang Ia bawa ke tengah-tengah umat manusia bukan saja janji bagi kehidupan mulia di masa yang akan datang, tetapi juga untuk masa sekarang (1 Tim. 4:8). ${ }^{{ }^{21}}$ Walau perlu ditegaskan ini bukanlah sosialisme Kristen ala Injili, karena bukan berdasarkan kekuatan politik, seperti Marxsisme. Bukan juga gerakan radikal (duniawi) ala teolog sekularis abad $20 \mathrm{M}$ yang lalu. Di sini gerakan keprihatinan sosial adalah panggilan Injil yang rohani dan dalam refleksi teologis yang mendalam, bukan sekedar kegiatan "baksos” dari aktivis-aktivis sosial gerejawi dalam Kristen liberal.

Saatnya melihat ketuhanan Yesus atas seluruh dunia dan alam, termasuk orang belum percaya sekalipun. Kuasa ketuhanan-Nya tidak harus dibatasi pada komunitas iman saja, tetapi mencakup seluruh ciptaan dalam semesta juga. Berdasarkan pemahaman akan Kristus sebagai Penguasa segala sesuatu sesuai pengakuan sejak semula, "even at creation Christ was already ruler for the whole universe was created in him and for him (Kol. 1:16-20)." ${ }^{22}$ Ini adalah pintu masuk menuju pembahasan Kristologi kekinian dalam implementasi doktrinal pada isu perbudakan gaya baru era ini. Yesus sebagai Tuhan adalah Raja di hati orang percaya, namun harus teraplikasi secara aktual dalam prinsip "Tidak ada Tuhan di dunia ini selain Yesus yang layak dipertuan oleh orang Kristen.”

\section{Orang Kristen Melihat Isu [Neo] Slavery sekarang}

Sejak sistem perbudakan dihapuskan dari dunia ini, maka secara normatif tidak ada lagi yang dinamakan perbudakan. Perbudakan selama masa lalu dinilai sebagi suatu kondisi manusia dan masyarakat dunia yang tidak berprikemanusiaan dan tidak ada kesetaraan antar manusia. Namun demikian, apakah secara otomastis tidak ada perbudakan lagi pada masa kini atau justru perbudakan secara tersistematis dalam kuasa politik yang dilegalkan secara modern dalam sistem perburuhan, sistem ketenagakerjaan, human trafficking, ekspor TKW/TKI legal dan non legal, ekploitasi buruh di bawah umur, wanita dengan upah murah dan tanpa jaminan ketenagakerjaan? Kelihatannya pengertian perbudakan telah

\footnotetext{
${ }^{21}$ Abraham Kuyper, Iman Kristen Dan Problema Social, terj (Surabaya: Momentum, 2001), 38, 39.

${ }^{22}$ Bloesch, Jesus Christ: Savior \& Lord, 223
} 
bermetamorfosis ke dalam hukum positif dan konstitusi, khususnya eksploitasi tenaga kerja upah murah tanpa jaminan hidup. Bukan rahasia lagi jika secara legal ada situasi dan kondisi yang disebut "perbudakan" juga pada era kini.

Secara umum, "budak” menunjuk pada seseorang yang dibeli untuk dijadikan budak atau abdi, hamba. Sedangkan perbudakan mengacu pada proses sosial di suatu masa, di mana segolongan manusia merampas kepentingan golongan manusia lain. Pada masa kini dapat terjadi secara sadar atau tidak, seperti yang dilihat sehari-hari pada "buruh kasar" atau "kuli," pembantu, jongos, yaitu sebagai sebutan bagi pekerja yang tidak terdidik (unskilled labourer) yang dapat diperlakukan dengan semena-mena, layaknya seorang budak pada zaman dulu. Seorang budak tidak memiliki dirinya sendiri sebagai manusia, hidup dalam ketakutan (secara mental, psikis bahkan fisik) dan tidak punya pilihan. Sementara secara sosial-politik, ekonomi, dan budaya adalah orang tertindas, marginal dan miskin secara terstruktur. Hal ini sangat jelas dengan kemiskinan yang dialami bersama keluarganya, terkait juga dengan hal: kesehatan, pendidikan, pemondokan, makan-minum dll. Sedangkan sistem perbudakan yang tersembunyi ini disokong secara legal formal oleh hukum, sehingga leluasa dipergunakan untuk mengekploitasi manusia baik tenaga dan jiwanya oleh golongan yang disebut "tuan."

Menurut laporan LSM dunia, International Justice Mission, “There are more slaves today than were seized from Africa in four centuries of transatlantic slave trade," "estimates that there are approximately 27 million slaves in the World Today. ${ }^{23}$ Departemen Luar Negeri Amerika Serikat mengeluarkan Laporan Tahunan Perdagangan Manusia 2010, disebutkan di dalamnya lebih dari 12 juta orang menjadi korban perbudakan moderen. Sejak sistem perbudakan dihapuskan dari dunia ini, kira-kira 150 tahun yang lalu di Barat, tepatnya 1827, mulai dari Prancis, Inggris, dan Amerika, secara normatif tidak ada lagi yang dinamakan "perbudakan" dalam arti sistematis dan legal. Perbudakan masa kini dimulai dengan apa yang dinamakan "perdagangan manusia" lintas Negara dan Internasional, bahkan Nasional. Adalah fakta bahwa

\footnotetext{
${ }^{23}$ National Geographic Magazine seperti yang dikutip dalam Mission Frontiers 29:4 (July -August 2007): 8
} 
human trafficking sekarang semakin marak di zaman modern yang dianggap lebih baik dalam konsep. Terungkapnya kasus-kasus penjualan manusia di media masa, hanyalah menunjukkan fenomena gunung es.

Sejalan dengan jiwa perbudakan global, human trafficking telah didefinisikan oleh Badan dunia, seperti PBB sbb.: "Perekrutan, pengiriman, pemindahan, penampungan, atau penerimaan seseorang, dengan ancaman, atau penggunaan kekerasan, atau bentuk-bentuk pemaksaan lain, penculikan, penipuan, kecurangan, penyalahgunaan kekuasaan atau posisi rentan, memberi atau menerima bayaran atau manfaat untuk memperoleh ijin dari orang yang mempunyai wewenang atas orang lain, untuk tujuan eksploitasi."24

Institute of Human Right and Business yang berkedudukan di Geneva mengindikasikan munculnya kembali perbudakan dalam apa yang disebut sebagai "modern slavery" terlihat dalam undangan pertemuan lembaga ini pada tanggal 16 November 2016. "US mission Geneva sendiri menyambut postingan dengan satu status tentang situasi neo slavery, yang indikasinya ... a conversation to discuss what concrete action in required to takle on the root causes of modern slavery."25

Di sini kita tidak mau mendalami kegiatan itu, tetapi istilah itu sudah muncul dan sedang serius ditangani isunya sebagai perbudakan masa kini. Ada catatan lanjutan "Facebook live event at 16:40 today via this page: Worker paid recruitment fees are one of the root causes of modern slavery. Governments, global companies and NGOs are coming together to call for collective action behind the principle that workers should not have to buy their jobs." Postingan itu dibagikan dua kali dan salah satunya berkomentar langsung mengenai sasaran, "Workers should not ever be exploited."26

Kelihatannya ada sinyalemen muncul kembali mengenai perbudakan dalam busana baru di dalam bisnis yang didorong UU mengenai ketenagakerjaan. Pada tingkat lokal Indonesia misalnya, walau UU no. 132003 pasal 5 ayat 3 a, jelas-jelas telah menolak "perbudakan" secara eksplisit... namun demikian tidak

\footnotetext{
${ }^{24}$ Protokol PBB tahun 2000 untuk Mencegah, Menanggulangi dan Menghukum Trafiking terhadap Manusia, khususnya perempuan dan anak-anak; (Suplemen Konvensi PBB mengenai Kejahatan Lintas Batas Negara).

${ }^{25}$ https://www.facebook.com/usmissiongeneva/photos/a.157785398875.116801.57207008875/10154371422238876/?type= $3 \&$ theater (diakses 12 November 2016), garis bawah dari penulis.

${ }^{26} \mathrm{htt} / /$ www.facebook.com/usmissiongeneva/photos/a.157785398875.116801.57207008875/10154371422238876/?type $=3$ \& theater (diakses 17 November 2016).
} 
ada jaminan bahwa hal itu terimplementasi dengan baik pada tingkat bawah, khususnya pada para buruh kasar, PRT, pekerja anak dll. ${ }^{27}$ Bahkan hukum tersebut dapat dicari celahnya untuk dipakai mengesahkan pelanggaran ketenagakerjaan di Indonesia. Secara politis ekonomi, sinyalemen pengabaian akan kesetaraan ini sangat nyata dikalangan Kristen.

Kalau perbudakan era modern Eropa dulu berintikan rasisme kultural ${ }^{28}$ dan merusak peradaban manusia secara global, namun neo slavery era pasca-modern ini terkait sistem ekonomi politik yang sangat kapitalistik dan kesejahteraan manusia lokal tertentu. Ini adalah cara kapitalisme modern yang didukung oleh sistem politik demokrasi. Jadi walau secara normatif sudah tidak ada perbudakan lagi, namun faktanya muncul perbudakan gaya baru yang terstruktur dan berkedok legal hasil proses kekuasaan demokratis. Proses perbudakan dewasa ini dinilai sebagai suatu kondisi manusia dan situasi dunia kerja yang tidak berprikemanusiaan dalam ketidakadaan kesetaraan antar manusia dan imperialisme kapitalis.Celakanya banyak di antaranya adalah majikan Injili yang mengenal Kristus adalah Tuhan dan Satu-satunya Tuhan di sorga mengatasi semua makhluk dan ras manusia.

Tentu tuduhan di atas menjadi serius jika terkait dengan Kristen Injili. Faktanya bayang-bayang neo slavery dalam norma-norma legal pada masa kini, khususnya atas pengaruh studi ekonomika modern ala kapitalisme. Ronald H. Preston melihat bahwa pengertian ekonomika sekarang berbeda dari ekonomi politis. Sebelumnya ekonomi dibahas dalam politik, namun era modern abad $20 \mathrm{M}$, ilmu ekonomika mandiri sebagai ilmu khusus tersendiri yang disebut oleh Adam Smith. Namun menurut Preston, "no great distintion made between economical and political issues" yang dibuat antara isu-isu ekonomi dan politik, "so the name political economy was appropriate." ${ }^{29}$ Pada awal bukunya, memang Preston menghadapi keprihatinan besarnya, bagaimana "Christian special theology should deal more effectively with the

${ }^{27}$ Berdasarkan Konvensi ILO no 109 tahun 1957 tentang Kerja Paksa dan Indonesia telah meratifikasi konvensi tersebut dalam Undang - Undang no 19 tahun 1999.

${ }^{28}$ Spencer \& Chris Rice, More Than Equal: Revised \& Expanded (Inervarsity Press, 2000), 189. Dengan alasan "we are all one in Christ."

${ }^{29}$ Ronald H. Preston, Religion \& The Ambiguity of Capitalism (Claveland; The Pilgrim Press, 1993), 18. Pada awal bukunya Preston menghadapi keprihatinan besarnya, bagaimana "Christian special theology should deal more effectively with the economic problems which loom large in human life and are so important for human well-being (1). 
economic problems which loom large in human life and are so important for human well-being." ${ }^{30}$ Ini tentu berbeda dengan kaum Injili yang melihatnya secara murni sebagai teologi yang teraplikasi, tanpa mengubahnya menjadi teologi sosial atau sosiologi. Untuk itulah teologi Injili harus melakukannya dengan jalur etika sosial Kristen sebagai studi kontekstualisasi doktrin dalam mengatasi persoalan dilematis. Sehingga doktrin kristologis selalu dinamis dan tidak mati sebagai pajangan saja. Setuju dengan Preston di atas bahwa "economic realities cannot be deduced from the bible or history of Christian thinking on the main of doctrinal themes." ${ }^{\prime 31}$

Ralph Winter, secara sadar mengatakan, "in one editorial we cant of course bring up a lot of "disruption" missiologies but this issues on the subject of what we might do about global slavery is clearly one disruptive issue." Selanjutnya menyarankan "we have to stop and think and rearrange our schedules, our mind, our perspective, do the things differently if we are going to hit this global problem the way God would want us to do." ${ }^{\prime 32}$ Ini adalah suatu pencerahan besar bagi orang Injili di Asia untuk berteologi dalam konteks yang memprihatinkan. Apalagi dalam situasi sekarang ini dipandang secara menyedihkan terkait dengan ekonomi, bahkan dalam konsep perbudakan global masa kini memandang secara tak beradab "baby is economic bonus" bahkan dikatakan "then, too, a baby is potential labor." ${ }^{33}$ Kalimat ini benar-benar slogan yang jelas bermentalitas perbudakan, walaupun tanpa istilah. Di Negara-negara miskin, bahkan mungkin juga dalam operasi neo-kolonialisme atau neo-imperialisme bangsa-bangsa maju atas Negara miskin, yang sekaligus dapat juga menunjukan fenomena slavery gaya baru ini. Kapitalisme memperbudak melalui sarana produksi sambil menguras hasil-hasil alam/bumi dengan menggunakan rakyat setempat; dan memperkaya para kapitalis, lalu penduduk lokal tetap miskin.

Bentuk perbudakan baru dan lama mungkin berbeda, tetapi esensi perbudakan sama saja, ketika seorang bekerja kepada tuannya dengan rasa takut, terancam, terindas, tidak berharga secara manusia, hanya

\footnotetext{
${ }^{30}$ Preston, Religion, 2. Tujuan kunci bukunya adalah "to make a reasoned plea for a greater Christian competence in tackling this issues," khususnya terkait dengan kapitalisme Barat dari perspektif pemikiran Kristen selama ini yang "has been inadequate and confused" dibandingkan dengan "democratic socialist critics" (2).

${ }^{31}$ Preston, Religion, 2

${ }^{32}$ Mission Frontier 15 secara khusus ia menduga sebagai munculnya apa yang disebut "Evangelical Taliban" (dalam konteks Amerika).

${ }^{33}$ W Stanley Money Ham, What Do You Say to a Hungry World (Waco TX, Key Word Book, 1975), 149.
} 
sebagi faktor pelengkap mesin. Sementara majikan mempekerjakannya dengan intimidasi yang tak bisa dilawan, karena keluarga membutuhkan penghidupan. Mereka tertindas secara fisik, batin, psikis, bahkan rohani. Manusia menjadi tidak berharga lagi; orang itu bukan milik dirinya sendiri dan bukan milik Tuhan, tetapi milik tuannya dan tuannya memperlakukan mereka dalam prinsip 'engkau milik saya,' maka itulah perbudakan. Dari dulu sampai sekarang perbudakan adalah idelogi dehumanisasi atas manusia ciptaan Allah dengan perlakukan dan sikap inhumanisasi atas pekerjaannya yang layak.

Dalam memandang masalah budak dan perbudakan, data dilihat dalam permasalahan etis.Melihat ke belakang pada perbudakan masa lalu, ada dua hal yang dapat diperhatikan. Pertama adalah menyangkut budak itu sendiri, sebagai makhluk yang menjadi barang perniagaan, selalu direndahkan harkat dan martabatnya, tidak merdeka dan diperjualbelikan. Kedua, sistem perbudakan, yaitu menyangkut penyebab timbulnya proses perbudakan dan terkait bagaimana hubungan tuan-budak secara sistemik. Perbudakan pun beraneka ragam, sesuai dengan kebiasaan sosial kemasyarakatan pada masa itu. Diantara penyebab perbudakan pada masa itu adalah: 1) Nafsu memperbudak (insting manusia) ketika merasa ras tinggi. 2) Ditaklukan dalam peperangan antar kelompok bangsa terhadap bangsa lain. 3) Khususnya karena terorisme, seluruh keluarga dan keturunannya dibiayai dan menjadi budak sistem terorisme. 4) Hukum bagi tindakan kriminal pada masa itu, seperti pencurian dan pembunuhan. 5) Jual beli manusia untuk diadu sebagai gladiator atau dipekerjakan di rumah. 6) Ada juga agama yang menghalalkan mengambil budak untuk seksualitas.

Tentunya tidak ada lagi perbudakan sistemik seperti yang dicontohkan di atas. Namun secara etis jelas nampak karena spirit moral perbudakan itu hadir di depan mata. Inti dalam perbudakan adalah masalah perikemanusiaan dalam perlakuan ketidaksederajatan, sehingga segolongan manusia mengalami ketakutan bekerja dan kehidupan yang tidak aman, terasa terjual dan terancam serta tanpa harapan masa depan. Jadi di sini belum tentu diperbudak secara fisik langsung, tetapi kalau pekerja tersebut merasakan hal yang demikian maka sudah dalam keadaan perbudakan, secara moral dan psikis. Di sini kita menilainya lebih dalam lagi, yaitu secara teologis.

Khususnya bagi Kristen sendiri, ini adalah pukulan bagi masa kini, mengingat catatan seorang penulis 
sekular seperti Stephen L. Carter menggali dokumen bahwa perdagangan budak Afrika dan penindasan pasca perang sipil di Amerika dibenarkan berdasarkan referensi sejumlah ajaran Alkitab dan doktrin Kristen..$^{34}$ Informasi ini menarik karena dikemukakan oleh seorang populis. Beberapa menyebarkan mitos bahwa para budak tidak mau dibebaskan dengan alasan hidup dan hanya sedikit yang ingin dibebaskan sebagai suatu yang tidak benar. Bahkan ada indikasi bahwa para misionaris Injili diizinkan memiliki budak sebagai persyaratan tugas pelayanannya ${ }^{35}$ Secara ekonomis hubungan mutualistik antara pengguna dan sang budak ditimbang dalam hubungan kerja. Di sinilah sistem kapitalisme dan komunisme pun syarat dengan jiwa diskriminasi dan penindasan manusia, setelah manusia lepas dari kolonialisme dan imperialisme di masa lalu.

\section{Panggilan Injili Untuk Berkristologi Kontemporer Pada Pergumulan Manusia}

Pada bagian ini, penulis berintensi untuk mengulas mengenai problem-problem kemanusiaan masa kini dari perspektif kristologis, khususnya dari pengakuan pribadi Injili mengenai kejuruselamatan dan ketuhanan Yesus di ‘dalam’ dunia ini, bukan 'atas’ dan ‘terhadap’ dunia ini saja.

\section{Pentingnya Konteks Segar dalam Refleksi Kristologis Injili}

Secara Injili, teologi yang benar adalah berdasarkan wahyu Allah yang hidup, dapat berfungsi dalam operasi hidup sehari-hari, dalam arti dapat teraplikasi secara normal dalam realitas kehidupan orang percaya. Ini yang dikatakan sebagai keseimbangan antara doktrin dan praktek dalam gerakan Injili harus berprinsip dalam beberapa unsur penting: otoritas Alkitab, spiritualitas, apologetik, penginjilan. ${ }^{36}$ Operasinya harus berpusatkan pada keunikan Kristus untuk era ini, dengan tetap berprinsip revelasional,

${ }^{34}$ Stephen L. Carter, The Culture of Disbelief: How American Law and Politics Trivilalize Religious Devotion (New York: Anchor, 1993), 83.

${ }^{35}$ Carter, The Culture, 181 77.

${ }^{36}$ Alister McGrath, A Passion for Truth: Intellectual Coherence of Evangelicalism (Downer Grove: InterVarsity, 1996), 173- 
soteriologis, doksologis, kerigmatis. ${ }^{37}$ Ini sejalan dengan identitas Injili sebagai “gerakan doktrinal” dalam teologinya, sekaligus membedakan dari kontekstualisasi kaum ekumenis yang pragmatis dan sosial, serta berbeda dengan teologi fundamentalis yang mandeg dalam dogmatisme yang mati. Kontekstualisasi doktrin begitu penting dalam situasi ini, karena teologi bukan hanya untuk para ahli teologi, tetapi untuk warga gereja juga, dalam arti pendewasaan iman umat. Artinya sebagai kaum Injili yang menekankan doktrin ortodoks harus tetap berhati-hati dalam pemikiran kekiniannya, agar tidak menyesatkan gereja atau menjadi anti-Kristen..$^{38}$

Upaya penghayatan kristologis secara kontekstual sudah dilakukan oleh banyak tokoh gereja, misalnya John Stott mengungkap tema-tema Yesus sebagai hasil pemahaman kontekstual di sepanjang sejarah: 1) Biarawan sempurna (Benediktus), 2) Pengutang feudal (St Anselmus), 3) Mempelai laki-laki (Bernard dari Clarvaux), 4) Teladan etika (Thomas Kempis), 5) Juruselamat (Martin Luther), 6) Sang Guru (Ernest Rena, Jefferson), 7) Mesias Yahudi (NT Wright), 8) Kristus atas dunia (misi abad 20: mulai dari Edinburgh 1910 sampai Lausanne 1974) ${ }^{39}$ Eksplorasi Karkkainen juga menunjukkan, bagaimana tradisi dogmatis mengenai Kristus dalam formulasi teologi Barat pun mengalami kontekstualisasi, sejak konsili Nicea hingga Karl Barth (Dialectical Christology), Rudolf Bultmann (Mythological Christology), Paul Tillich, (Existentalist Christology), John Zozioulas (Communion Christology), Karl Rahner (Transcendental Christology), Jurgen Moltmann (Messianic Christology), Wolfhart Pannenberg (Universal Christlogy), Norman Kraus (Desciples' Christology), Universalist Christology (John Hick), bahkan Stanley Grenz, (Evangelical Christology). ${ }^{40}$ Ini semua menggambarkan bahwa setiap pemikiran kristologis mengandung konteks pergumulannya, pada setiap orang di zaman dan daerahnya sendiri-sendiri. Sepanjang sejarah terus berkembang bahkan ada yang berubah, sampai ke non-Barat, seperti: Christ as Liberator (Latin), Christ as

\footnotetext{
${ }^{37}$ McGrath, A Passion, 36-47. Bagi saya prinsip mimetik ini sesuatu yang berbahaya dalam dunia masa kini, karena penuh dengan rasa arogan, agresif, persaingan dalam pendekatan apa yang dinamakan "eksklusivisme"; keunikan Kristus tidak perlu menjadi eksklusivisme agama.

${ }^{38}$ Untuk topik ini pembaca diudang melihat situasi mengenai penelitian Yesus era ini dalam "Situasi Kekristenan Era Ini dan Penilaian Kristologis Injili” dalam Jurnal Teologi Stulos, Vol. 14 No. 1 (Mei 2015): 21-50.

${ }^{39}$ John Stott, Kristus Yang Tiada Taranya, 75-115. Bahkan ada juga perspektif pengaruh Yesus pada kehidupan dan ajaran orang-orang tertentu secara pribadi, seperti Mahatma Gandhi, Wilberorce, Tolstoy, Martin Luthar King, Jr., dll (125-164).

${ }^{40}$ Velli-Matti Karkkainen, Christology: A Global Introduction, Ecumenical, International, and Contexttual Perspective (Grand Rapids: Baker Book, 2003), 111-179, 189-212.
} 
Ancestor (Africa) and Christ as universal Savior (Asia). ${ }^{41}$ Sepintas ada bahaya mengintip, namun kontekstualisasi kristologi bukanlah suatu yang tabu, tetapi keharusan dari dalam studinya.

Jadi doktrin Barat yang banyak dipergunakan pelajar Asia selama ini pun tidak turun dari langit, tetapi ada perhatian dan keprihatinan pada konteks lokalnya sendiri dalam merumuskan proposisi ajarannya. Bahkan Alkitab mengandung konteksnya sendiri dalam proses inskripturasi firman melalui inspirasi organiknya. Di sinilah pentingya kajian applied Systematic theology, sehingga kaum Injili tidak alergi dengan istilah "kontekstual[isasi]" dan tidak bersikap negatif pada panggilan kontekstualisasi doktrin, khususnya dalam mengkonstruksi doktrin-doktrin alkitabiah untuk pergumulan manusia saat ini. Tentunya istilah "teologi kontekstual" dapat dikritisi sebagai kesalahan tautologi, mengingat unsur "logi" dalam istiah “teologi" itu sendiri mengimplikasikan adanya konteks berpikir dan pemikiran teologi di mana berada. Kontekstualisasi Injili dapat diterima sebagai suatu usaha sadar mendaratkan ajaran-ajaran alkitabiah mengenai keutamaan Kristus (bahkan keunikan) pada situasi dan kondisi yang berkembang dalam ruang dan waktu. Tanpa itu, maka menjadi ajaran kering dan tumpul jika tidak teraplikasikan. Hal ini bukan berarti teologi dalam gerakan Injili hanya untuk golongan akademisi, yang selama ini dituduh "elitisme teologi." Walau harus terimplemantasi secara praktis, kristologi bukanlah sekedar "hobi" omong-omong tentang Kristus secara agama saja.

Belajar dari pemikiran McGrath yang menunjukan beberapa kelemahan kekristenan dan kegagalan teologisnya di Asia pada abad 19 di China dan Jepang, dikarenakan teologi tidak cukup relevan dan makhluk asing secara budaya, dan kekristenan hanya sebagai barang import dari negeri bule, ${ }^{43}$ khususnya terkait dengan applied doctrines sebagai dasar dalam kontekstualisasi teologi Injili, karena inti gerakan Injili adalah gerakan doktrinal. Dengan memprihatinkan konteks situasional-kondisional dapat dikategorikan menjadi tiga area manusia: 1) Agama/keyakinan, 2) Kultural/adat, 3) permasalahan kemanusiaan/ pergumulan hidup. Tentunya kaum Injili sudah familiar dengan kontekstualisasi kultural dan agama,

\footnotetext{
${ }^{41}$ Karkkainen, Christology, 222 dst.

${ }^{42}$ McGrath, A Passion of Truth, 18 dst.

${ }^{43}$ Alister McGrath, Evangelicalism and the Future of Christianity (Downer Grove: Intervarsity, 1995), 113.
} 
khususnya dalam teologi misi atau misiologi ala Barat, namun sangat kurang dalam permasalahan hidup manusia dari perspektif doktrin. Khususnya Indonesia selama ini menjadi konsumen teologi Barat dan berbangga diri dengan rumusan-rumusan Barat yang berbeda cara pikir, kondisi intelek, dan pergumulan religiusnya.

Namun harus tetap diingat bahwa melupakan aspek kejuruselamatan dari ketuhanan Yesus adalah suatu bentuk pengkhianatan kristologis. Pembacaan dalam Perjanjian Baru yang hanya historis akan menjadi yesusologi dan tidak pernah menjadi kristologi, sebagai suatu usaha teologi palsu bagi gereja-gereja. Injil bukanlah buku cerita alamiah tentang Yesus sebagai Rabbi saja, tetapi wahyu inkarnasional yang menyelamatkan. Kita harus menolak apa yang dikatakan "Unchristological Christology" yang kristenologi saja, sebagai kristologi palsu. Untuk itu Kristologi Injili harus menimbang tekanan kajian 'Yesus imani' dan ‘Kristus historis’ sekaligus, karena faktor inkarnasi ilahi dan karya kehidupan dunia khususnya penebusanNya. Di sini perkataan Carl Brateen benar mengenai sebutan “bukan kristologi” ketika kristologi membisu mengenai kebangkitan dan kenaikan, dan "sebagai suatu yang tidak layak disebut Kristen"44 lagi.

\section{Keprihatinan Kristologis-Etis pada Isu Perbudakan}

Seseorang sempat mengakui kelemahan Kristen dalam sejarah dunia dalam beberapa titik buta. Salah satunya soal "perbudakan" di masa lalu, dengan pertanyaan, "Bagaimana [mungkin] umat Kristen yang percaya kepada Injil bisa dengan mudah membenarkan perbudakan atas manusia lain?” Suatu jemaat dengan niat baik beribadah bersama pada hari Minggu dengan mudah menggunakan firman Allah untuk menjustifikasi perlakuan atas laki-laki, perempuan, dan anak-anak sebagai properti yang bisa digunakan. ${ }^{45}$ Bahkan dapat dikatakan irioninya, "saya bisa menjalani kehidupan Kristen dan bahkan menjadi pemimpin gereja, sedangkan pada saat yang bersamaan mengabaikan sisi jahat yang tidak saya sadari.” Sementara

\footnotetext{
${ }^{44}$ Chris Wright, Tuhan Yesus Memang Khas Unik: Jalan Keselamatan Satu-Satunya, terj. (Jakarta: YKBK/OMF, 2003), 55.

${ }^{45}$ Pengakuan Davit Platt, Radical, Mengikut Yesus Tak Peduli Berapa pun Harganya. Terj (Surabaya: Perkantas Jatim, 2010), 115-116. Menurutnya "ini mengerikan' dengan memberikan bonus sepotong ayam goreng di hari natal" sebagai titik buta dalam mengikut Yesus yang perlu dicelikan.”
} 
memberitakan Yesus ke sana-sini untuk menjadikan mereka murid, namun mengabaikan perintah Tuhan mengenai sesama manusia.

Dalam buku Radikal, karya Platt mengambil sub judul "Realisme Kehidupan dalam Mengikut Yesus Seberapapun Harga.” Secara umum ia ingin menempatkan Yesus sebagai Raja dan Tuhan dalam hati dan kehidupan secara faktual. Secara keseluruhan ia melihat dengan jeli 'gagasan-gagasan ideologi dunia dan nilai-nilai duniawi yang lazim dalam kebudayaan dan gereja, namun bertentangan dengan Injil.' Ia menyasar untuk memeriksa kembali pemikiran dan melepaskan praktek duniawi dalam mengikut Yesus. ${ }^{46}$ Libberton dalam tulisannya mengenai ibadah Kristen yang terkait dengan panggilan ketidakadilan sosial menggambarkan ketercengangannya, "bahwa lebih dari 25 juta orang di seluruh dunia masih hidup dalam perbudakan hari ini," ${ }^{\prime 7}$ dikatakannya lagi "sejarah menunjukan perbudakan yang dibela oleh banyak orang yang tahu Kitab Suci dari depan sampai belakang, namun imajinasi mereka tidak berubah." ${ }^{48}$ Bahkan orang memakai Alkitab untuk menjalankan dan merumuskan konsep perbudakan modern sampai sekarang.

Beberapa orang yang telah ditebus dari perbudakan dosa oleh kemurahan Tuhan tidak mau membagi kemurahan itu kepada orang inferior. Layaknya seorang yang banyak hutangnya dihapuskan hutangnya, tetapi tanpa belakasihan kepada orang yang berhutang sedikit kepadanya (lih.Mat.18:23-30). Apakah ini yang dimaksudkan seorang lahir baru atau ciptaan baru, mengapa kita melakukannya, mengapa kita membiarkannya dan mengapa kita enggan merefleksikannya dari perspektif ketuhanan Yesus yang kita agungkan? Ini suatu ironi bahkan kontradiksi dalam kekristenan sampai kini. Dari pandangan sorotan terhadap yang berbeda, DA Carson menunjukan bahwa realitas-realitas perbudakan dalam Kekaisaran Romawi agak berbeda dengan perbudakan yang terjadi di Barat" demikian penjelasannya, "Di Barat tidak ada perbudakan yang merupakan akibat dari orang-orang yang secara rela menjual diri mereka sendiri akibat...kebangkrutan... Dalam dunia Romawi Kuno ada budak-budak dari banyak ras dan budaya: mungkin Inggris, dari semenanjung Italia, orang Yahudi, orang Afrika... individu bebas dari semua bangsa

\footnotetext{
${ }^{46}$ Platt, Radikal, 150.

${ }^{47}$ Mark Labberton, Bahaya Ibadah yang Sejati, terj (Surabaya: Perkantas Jatim, 2011), 143. Keprihatinan teologis kita sama dengan yang diungkapkan dalam catatan akhirnya, Jika Yesus adalah Tuhan "Bagaimana itu menjelaskan pemahaman orang Kristen tentang kekuasaan di dalam dunia?” ( 249).

${ }^{48}$ Labberton, Bahaya, 195.
} 
ini, di antaranya orang berpengaruh dan terpelajar. Itu berarti bukan satu ras tertentu saja." ${ }^{49}$ Namun sebaliknya di Barat semuanya hampir dan pastinya orang kulit hitam yang menjadi budak. Seakan-akan ada pengasosiasian psikologis antara budak dan kulit hitam. Ini adalah pengakuan 'bule' Injili masa kini.

Dengan menganggap bahwa perbudakan bukan semata-mata isu penindasan manusia atas manusia, tapi di sisi lain adalah bagian utuh dari sendi dasar perekonomian suatu bangsa pada waktu dulu. Sehingga dianggap menghilangkan perbudakan berarti meruntuhkan sendi-sendi dasar perekonomian dan bangsa. Kemudian perbudakan dilegalkan dalam hukum yang positif dan dibenarkan oleh undang-undang, sehingga sistem perbudakan memiliki budak, menjual, menukar dan mempertaruhkannya, adalah tindakan yang sesuai dengan hukum setempat. Jika ada budak yang melarikan diri dari tuannya, maka tidak langsung bebas secara hukum atau boleh diambil oleh yang lain, karena akan terkenai tindakan melawan hukum. Membebaskan budak dengan tebusan adalah satu-satunya jalan yang dibenarkan saat itu. Bahkan dibeberapa hukum posistif ada bangsa yang mengabsahkan untuk menyetubuhi budak perempuan bahkan laki-laki. Itu bukan hal yang aneh atau melanggar hukum. Abdurrahman Wahid pernah menyatakan adanya TKW di negara-negara Arab sebagai "amatun" atau budak yang bisa diperlakukan apa saja. Pada masa kini, tentunya pernyataan ontologis ini dapat nilai negatif jika dilihat dari segi etis.

Dikatakan sebagai suatu fakta situasi perbudakan, "Ekonomi dengan negara maju yang biasanya Kristen dan percaya Yesus sangat bergantung pada pabrik-pabrik di negara berkembang, di mana pekerjapekerja diperas dan diperbudak. ${ }^{" 50}$ Kadang-kadang orang-orang maju yang beragama Kristen dan dicap mengikut Yesus memanipulasi dan berlagak tidak tahu kondisi tersebut. Hukum memperbudak orang kecil kepada penguasa dan orang kaya atau memperbudak orang miskin di bawah orang kaya melalui UU dan hukum positif. Jadi pada masa kini, ada petunjuk bahwa hukum berpotensi memperbudak melalui suatu usaha legislasi dan hukum tertulis yang hanya memihak kapitalisme.

\footnotetext{
${ }^{49}$ D.A. Carson, Kasih di Tempat-Tempat yang Sulit, terj. (Surabaya: Momentum, 2007), 132-33. Dalam hal ini pola tersebut ada di dalam kedua belah pikiran golongan, bule dan negro di Barat.

${ }^{50}$ Andy Crounch, Menciptakan Budaya: Menemukan Kembali Panggilan Kreatif Kita, terj. (Surabaya: Perkantas Jatim, 2011), 78 .
} 
Selanjutnya, pengertian umum untuk memahami perbudakan, di mana spirit inti selama ini tetaplah sama, yaitu suatu kondisi manusia tidak dimanusiakan oleh manusia itu sendiri. Cara-cara dan sikap yang mentuhankan diri dari para pengusaha yang menganggap manusia pekerjanya hanya barang pelengkap produksi adalah benih perbudakan yang kemudian dilegalkan dalam hukum-hukum Negara. Dengan demikian secara tidak disadari atau tidak diakui, bangsa-bangsa modern ini fasih mempraktikkan perbudakan bahkan tidak disadari masih melakukan perbudakan secara sistemik. Artinya secara ideologis, perbudakan bukan soal primitive peradaban bangsa-bangsa di masa lalu, tetapi pada masa kini juga.

\section{Makna Kristologis mengenai Relasi “Tuan-hamba” bagi Kekristenan Sekarang}

Kristologi Injili tidak seharusnya mengalami kemandulan berpikir dalam mencanggihkan pendapatpendapat ontologis lama saja. Hal ini mungkin karena akademisi Injili memberi contoh dalam ketidakmelekan teologi atau tanpa buah pikiran baru yang mendalam. Mengingat kembali ungkapan dari reformator Luther, yang sering dilupakan kaum Injili, sola experientia facit theologum (hanya pengalaman yang membentuk teolog). Jadi di sini doktrin kristologinya harus terbuka pada refleksi konteks segar gerejagereja agar dapat mengenal Yesus dalam pergumulan setempat. Sebenarnya ada jalan kontekstual-etis untuk mengurusi keadaan manusia kekinian, khususnya fokus ketuhanan Yesus di dunia, atas dunia, dan untuk dunia, sekaligus menatalayani dunia. Dengan demikan ada kesempatan untuk menteologikan doktrin Kristus dalam konteks Asia secara wajar, bukan hanya ikut-ikutan demam 'teologi kontekstual' dari nonInjili. Kaum Injili dapat merumuskan kembali kristologinya pada situasi ini dalam prinsip-prinsip di bawah:

\section{Menjernihkan Tuduhan dalam Sejarah Misi Gereja}

Beberapa orang telah menuduh agama Kristen sebagai “biang kerok” sistem perbudakan pada masa lalu, karena didasarkan pada kenyataan sejarah. Selain itu mungkin karena penggunaan kata "budak" dalam Alkitab yang oleh beberapa petualang kolonialisme dan imperialisme dijadikan tameng untuk membudak ras lain. Namun sebenarnya itu tidak dapat dijadikan alasan untuk menuduh kekristenan dan Alkitab sebagai sumber ajaran perbudakan di dunia ini. Karena deskripsi alkitabiah tidak harus diartikan pengajaran 
instruksional Alkitab. Bahkan implikasi kristologi mengajarkan untuk menolak sama sekali ide perbudakan, dan faktanya pengaruh Kristenlah yang menghapuskan sistem perbudakan dari Negara-Negara Barat; asalkan cukup pengenalan akan Ketuhanan Yesus dan martabat manusia. Wilberforce misalnya, meninggalkan warisan terbaik bagi kaum Injili dalam menghapuskan perbudakan di Inggris. Dalam hal ini beliau menegaskan ketidakcukupan konsep-konsep penting tentang kekristenan, konsep tentang hakikat manusia, tingkah laku Kristen dan studi teologi. ${ }^{51}$ Di sini Kristologi etis menjadi sangat penting untuk memahami manusia dan dunia untuk melampaui kristologi-ontologis Injili selama ini.

Mungkin perbudakan sistematis di atas sudah tidak ada lagi di tengah rumah tangga Kristen sekarang. Tetapi di dunia kerja masih terlihat pembantu terpisah secara sistematis, karena pandangan dunia menganggap tidak layak duduk bersama dan menikmati makanan yang sama. Sikap diskriminasi status dan mentalitas non-emansipasi masih banyak di hadapan pengikut Kristus, walau tanpa ideologi perbudakan. Hal itu menyangkut wawasan dunia Injili yang berdasarkan Alkitab, karena ada banyak orang mengaku "lahir baru" tanpa memiliki wawasan dunia alkitabiah. ${ }^{52}$ Bahkan dalam pengalaman Injili Barat, sikap rasisme, --yang saya anggap sebagai akar ideologis sistem perbudakan masa lalu-- masih nyata dalam cara hidup praktis kaum Injili di Amerika (khususnya dalam bertetangga dengan non Barat, seperti Negro, Asia, Latin). Walau itu bukan permasalahan orang Injili belaka, tetapi merata sebagai suatu ras bangsa putih. Jeritan Ron Sider seharusnya menjadi peringatan dan pembelajaran bagi kaum Injili, termasuk Injili Indonesia, di mana buku tersebut diterjemahkan sebagai bahan peringatan dan pelajaran, ${ }^{53}$ untuk berteologi didalam konteks, khususnya merumuskan doktrin ketuhanan Yesus masa kini.

Skala perbudakan Barat dahulu berintikan rasisme kultural ${ }^{54}$ dan merusak peradaban secara global.

${ }^{51}$ Lih prinsip-prinsip dan perjuangan William Willberforce menghapuskan sistem perbudakan di Inggris melalui majelis tinggi dalam Mark Shaw, 10 Pemikiran Besar dari Sejarah Gereja: Panduan Pengambilan Keputusan yang Akan Menentukan Arah Gereja Anda, terj. (Surabaya: Momentum, 2003), 228 dst. Lihat juga Real Christianity: Contrasted with the Prevailing Religious system (Multnomah Press, 1982 [1829]).

${ }_{52}$ Survei George Barna mengingatkan bukan hanya ada dua golonan Kristen, Injili dan non Injili, tetapi juga dua golongan pandangan hidup yang berbeda di dalam kalangan Injili, yang berpandangan dan tidak berpandangan dunia alkitabiah. Dan ini dapat kita terima sebagai suatu kenyatan (Lih George Barna, Berpikir seperti Yesus, terj., Gospels Press, 2006) 54-58

${ }^{53}$ Secara keseluruhan ini telah diungkap oleh Ron J. Sider dalam Skandal Hati Nurani Injili, terj (Surabaya: Perkantas Jatim, 2003).

${ }^{54}$ Lih Spencer \& Chris Rice, More Than Equal: Revised \&cExpanded ( Downers Grove: Intervarsity Press, 2000), 189 
Namun perbudakan sekarang tidak selalu terkait budaya ras tertentu lagi, tetapi sistem ekonomi politik yang sangat menekan dan dehumanisasi. Dalam situasi ini perlunya rekonsiliasi dengan senjata murninya yang paling ampuh untuk masa kini, yaitu "forgiveness" dan pentingnya Kristen menamakan "Culture of grace." ${ }^{55}$ Di sini perlunya pemisahan suatu negara hitam yang didanai secara federal "sebagai restoration for slavery." Walau ide radikal ini tidak diterima secara umum dengan alasan politik peradaban, "if we can do itu for Isreal why not for Black?"56 Kingship dan lordship ada dalam berita Kerajaan Allah di dunia ini. Ia adalah Raja bagi gereja-Nya dan atas seluruh dunia. Ketuhanan-Nya bukan hanya terkait keselamatan dalam arti keilahian-Nya semata. Kita menerima-Nya sebagai Allah yang bertahta dalam hati melalui Roh Kudus, juga Tuhan Allah atas semua orang di dunia, Pencipta dan Pemelihara. Ketuhanan Yesus dalam hati orang percaya dan atas seluruh dunia global.

\section{Mendasarkan Ajaran Alkitabiah mengenai Budak dan Tuan}

Dalam Alkitab istilah budak tidak dapat langsung dimengerti sebagai perbudakan sistemik seperti zaman modern. Walau Alkitab mencatat sebagai fakta antropologis setempat tentang budak dan tuan masa lalu, tetapi tidak menyokong perbudakan. Teks Alkitab demikian tidak bisa dipakai sebagai suatu ajaran Kristen secara komprehensif pada masa kini.

Memang zaman modern mengambil alasan melalui istilah-istilah budak yang ada dalam Alkitab, namun tidak boleh dipakai sebagai dasar ajaran untuk perbudakan. Beberapa orang menuduh kekristenan mengajarkan dan mendukung perbudakan sejak semula. Ini suatu tuduhan keliru sama sekali. Ketika orang melakukan perbudakan berdasarkan Alkitab adalah sesat dan ajaran bidat. Memang dalam Alkitab ada deskripsi bagaimana memperlakukan budak, tetapi itu suatu perlakuan terhormat ( U1. 15:12-18). Paulus mengajarkan hubungan tuan yang harus memperlakukan budaknya, “ ... jauhkanlah ancaman. Ingatlah, bahwa Tuhan mereka dan Tuhan kamu ada di surga dan Ia tidak memandang muka” (Ef. 6:9). Memang

\footnotetext{
55 Rice, More Than Equal, 145, 246 According to Marthin LutherKing Jr. forgiveness is not just an occasional act, it is an permanent attitude" (247).

${ }^{56}$ Rice, More than Equal, 31.
} 
benar Paulus pernah menghimbau (seorang Kristen) yang menanggung perbudakan di bawah non Kristen atau Kristen, “ ... hendaknya menganggap tuan mereka layak mendapatkan segala penghormatan, agar nama Allah dan ajaran kita tidak dihujat orang" (1 Tim 6: 1). Secara doktrinal ini adalah deskriptif dan eksplanasi hubungan pada waktu itu, bukan instruksi untuk melakukan perbudakan di masa dulu ataupun mendukung roh perbudakan pada masa kini, seperti yang dituduhkan beberapa orang.

Dalam Alkitab "budak" ada batas-batasnya sampai tahun Sabat dan tahun Yobel (Ul. 15:12). Semuanya harus dilepaskan dan dikembalikan sebagai prinsip pemulihan (Ul.15:13-15)). Dalam sejarah umat PL, relasi tuan dan hamba biasanya karena masalah kalah perang, utang, dan orang asing. Walau relasi hamba dan tuan dalam agama dan sosial biasanya berdasarkan relasi belaskasihan (mercy) dan ketakutan. Semakin baik dan mengabdinya hamba tersebut, maka semakin berbelaskasihanlah tuannya. Semakin budak tidak rajin, maka tuanya semakin menindas tanpa kasihan. Rumusnya adalah harus pandai-pandai berbuat baik di hadapan tuannya, supaya mendapat belaskasihan. Namun belaskasihan di sini bukanlah anugerah seperti yang kita kenal dalam kekristenan. Anugerah melampaui belas kasihan dan mencakupnya dalam hubungan kekeluargaan dan kemanusiaan, Jika belas kasihan manusia tidak dilandasi anugerah Allah, maka hubungan tersebut menjadi suatu ketakutan dan ancaman dalam mentalitas perbudakan.

Selanjutnya dalam Kolose 3:11, Alkitab (NIV) mengajarakan kesetaraan dan tidak ada lagi perbedaan manusia di dalam Kristus, di dalam kesetaraannya, "Here there is no Gentile or Jew, circumcised or uncircumcised, barbarian, Scythian, slave or free, but Christ is all, and is in all." Hal ini diulang dalam 1 Korintus 12-13 For we were all baptized by one Spirit so as to form one body—whether Jews or Gentiles, slave or free - and we were all given the one Spirit to (1 Kor12:13). Jelas dan nyata bahwa kata "slave" dituliskan untuk menunjukan tidak boleh ada perbudakan di dalam Kristen dan dilakukan oleh Kristen. Karena Tuhan kita satu di sorga, semuanya adalah saudara. Jadi tidak boleh ada perlakuan budak dan spirit perbudakan dalam kerja dan usaha manusia. Kekristenan harus mendorong terus penghapusan perbudakan dalam dunia kerja kapitalis. Karena secara tegas Alkitab mengatakan "The Spirit you received does not make you slaves, so that you live in fear again" (Roma 8: 15). Di sini ditegaskan tidak ada lagi status budak dan tuan dan tidak boleh ada relasi memperbudak dan diperbudak di dalam Kristus sebagai 'batu penjuru" 
bagi yang berbeda-beda. Secara keseluruhan, Alkitab tidak mengajarkan perbudakan manusia, walaupun ada deskripsi mengenai fakta perbudakan. Alkitab hanya melaporkan situasi faktualnya. Di dalam perbedaan-perbedaan fisik dalam ras tidak harus menjadikan seseorang secara tidak manusiawi. Artinya semuanya setara dan sama kemanusiaannya. Kemajemukan status sosial-ekonomi adalah dasar untuk persatuan dan kesatuan dalam iman rohaniah. Kristus telah membebaskan kita dari perbudakan dosa dan menjadikan kita seorang pelayan. Prinsip servant bukan slave yang tidak mempunyai dirinya sendiri lagi. Anak pun dapat melayani dan sebagai pelayan di hadirat Allah namun bukan diperbudak, Yesus datang sebagai Pelayanan walau juga bertindak sebagi hamba secara teologis, bukan antropologis.

Sebagai Allah yang berinkarnasi, Yesus datang untuk menebus orang percaya dari perbudakan dosa. Soteriologi PB memakai kata exagorazo untuk menginformasikan pada kita ditebus dari "pasar dosa" dan dilepaskan menjadi orang merdeka bahkan diadopsi menjadi Anak Allah. Dengan darah Yesus kita adalah anak-anak Allah, bukan budak iblis atau dosa lagi. Kita adalah hamba Allah yang merdeka, pelayan Allah yang Maha Baik. Hubungan tuan-hamba dalam kekristenan bukan sekedar hubungan belaskasihan -tuan dan budak- tetapi juga hubungan anugerah antara Bapa dan Anak. Dasarnya adalah anugerah telah diterima dan belaskasihan Anak lah bersifat didaktik sebagai anak-anak Allah. Dia menghajar kita sebagai anakNya, bukan budak-Nya. Namun kita dengan sukacita memperhamba diri dan melayani Allah.

\section{Keseimbangan antara Ketuhanan dan Keselamatan}

Bagi Ladd, Injil memakai sebutan atau gelar Tuhan kepada Yesus, "suggests the title belongs primarily to Jesus as the risen and the ascended one." ${ }^{57}$ Namun Kristen sekarang mengartikan ketuhanan Yesus sebagai sesuatu yang digunakan secara simultan untuk Allah dalam rangka memuliakan Yesus. Ini yang saya katakan sebagai the lordness of Jesus. Keilahian Yesus yang sejak pra inkarnasi dan sebagai Mesias yang dijanjikan sebagai ilahi. Selanjutnya dalam Paulus "ketuhanan Yesus lebih menunjukan pada karya-Nya bukan status-Nya saja bagi orang percaya dan dunia ini." "The heart of early Christian

\footnotetext{
${ }^{57}$ George Eldon Ladd, A Theology of New Testament (Grand Rapids : Wm Eerdmans, 1974), 338 Secara teologis gereja purba mengenal dan meninggikan Yesus sebagai Tuhan dan Mesias juga, setelah kebangkitan dikatakan "Allah telah membuat Dia Tuhan maupun Mesias (2:36) yang menurut Ladd, "In the primitive kerugma, Jesus as become Lord."
} 
confession as the Lordship of Jesus Christ means what God has done in Jesus \& personal submittion to \& acception a his lordship." ${ }^{.58}$

Menurut Guthrie, dalam Injil-Injil, Tuhan bagi Yesus sering dimaksudkan sebagai gelar kehormatan agak mirip dengan gelar "tuan pada percakapan populer" dan "mungkin sama dengan master dan guru”59 namun lebih dari itu Tuhan bagi Yesus bukan sebagai gelar khusus yang digunakan sesudah kebangkitan-Nya, dalam arti "ketuhanan ilahi" ${ }^{60}$ yang saya sebutkan sebagai lordness of Jesus, mengingat Ia adalah ilahi pra inkarnasi dan setelah inkarnasi tetaplah Allah dan manusia seperti di dasarkan pada InjilInjil dan Surat Paulus, walau makna kyrios digunakan secara simultan untuk Allah dan Yesus yang ditinggikan. Itulah sebabnya kaum Injili memformulasikan Yesus adalah Manusia (100\%) sejati dan Allah (100\%) sejati, lalu menekankan sisi keilahian-Nya untuk gelar ketuhanan-Nya, seperti lordness-Nya, dan melupakan lordship Yesus atas kehidupan umat dan dunia ini. Ini yang dikatakan "kristologi dari atas" dan meninggalkan perspektif sebelumnya, dari bawah dan dibelakang” seperti yang disarankan. Sejak semula sampai zaman modern kaum kristiani lebih mengutamakan keilahian dan ketuhanan Yesus dalam arti lordness, bukan lordship-Nya. Baru setelah abad modern sampai sekarang, orang non Injili berposisi ekstrim melawan dengan penekanan sekular dan agama-agama pada kemanusiaan Yesus sebagai Yesus historis yang tidak kristologis.

Dari tulisan Fuller yang menelusuri formulasi kristologi terkait formasi cerita-cerita kebangkitanNya, kita dapat melihat keunikan pemahaman orang percaya akan ketuhanan Yesus, khususnya dari Kisah Para Rasul 2:36 adalah terkait gelar kristologi ketuhanan Yesus bergaya "helenistic jewish" adalah "The risen One from the resurrection as exalted kyrios" yang babak sebelumnya "the risen one was identified with the coming the Son of man (Jewish); ${ }^{61}$ dalam teks ini Yesus: "is exalted ti and active reign as Kyrios

\footnotetext{
${ }^{58}$ Ladd, A Theology, 339.

${ }^{59}$ Donald Guthrie, Teologi Perjanjian Baru, terj. ( Jakarta: BPK Gunung Mulia, ) 1: 327, 328

${ }^{60}$ Ladd, $A$ Theology, 339. Selanjutnya ia berpendapat "it is therefore amazing to find the term use in the same time of both Jesus and God.... in practically interchangeble context."

${ }^{61}$ Reginald H. Fuller, The Formation of the Ressurection Naratives (Kentukcy: Fortress Press, 1983), 21-222. Dia membagi tiga formulasi kristologi berdasarkan tradisi paskah mula-mula yang terdapat dalam 1 Kor 15: a) the death, b) the burial, c) ther resurrection, d) the appearences.
} 
or Christos" ${ }^{62}$ yang ini menunjukan ketuhanan Yesus, penjelasannya agak berbeda bukan hanya aktif, intensif, responsive dalam pemerintahan-Nya melalui gerejaNya dan orang percaya. Ini terkait dengan gelar kristologis Yesus sebagai "Nabi" yang ditransform pada Gereja yang adalah tubuh Kristus dan Kristus sebagai Kepala gereja setelah kebangkitan-Nya. Pada titik ini gelar Tuhan bagi Yesus mencakup jabatanNya sebagai Raja dan Nabi bagi gereja-Nya. Namun dalam kenabian dan Injil Kerajaan-Nya, berfungsi sebagai referensi sosial bagi dunia yang bengkok dan agen transformasi sosial dalam masyarakat.

Secara teologis gereja purba mengenal dan meninggikan Yesus sebagai Tuhan dan Mesias juga, setelah kebangkitan dikatakan "Allah telah membuat Dia Tuhan maupun Mesias” (Kis.2:36). Selanjutnya ini adalah gelar peninggian Yesus dengan panggilan Tuhan yang setara dengan Allah itu sendiri. Secara rohani, gelar Tuhan itu sangat terkait dengan gelar Juruselamat-Nya. Bahkan ketuhanan atas semesta adalah pemeliharaan dan ciptaan adalah natural, sedangkan ketuhanan atas iman adalah ketaatan spiritual. Keduanya bersatu dalam tugas Kristen atas penebusan ciptaan yang harus dimengerti secara rohani sebagai sarana Allah di masyarakat, khususnya dalam suara kenabian gereja di tengah dunia yang semakin tidak bertanggungjawab mempergunakan ciptaan ini.

\section{Kaum Injili Melampaui Kristologi Ontologis Menuju Kristologi Etis}

Menurut Mark Achtemeier, tema ketuhanan Yesus dapat dilihat dari tiga sudut secara bersamaan: 1). lordship of incarnate Word, 2) the lordship of crucified the Son of man, 3) The lordship of the risen and exalted son of God. ${ }^{63}$ Bagi kaum Injili, ketiganya adalah kumulasi perspektif kristologi "dari atas" "dari bawah dan belakang" dan "dari depan".

Kaum Injili harus meluaskan refleksi kristologis dari perspektif from above sampai perspektif from afore secara seimbang. Tidak ada salahnya penekanan from above dalam Kristologi Injili, tetapi tidak harus melupakan from below bahkan from afore. Di sini orang Kristen harus mengejawantahkan pengakuan akan ketuhanan Yesus yang bangkit dari kematian dan menebus kita untuk mengasihi dunia ini. Apa akibat dari

\footnotetext{
${ }^{62}$ Fuller, The Formation, 128.

${ }^{63}$ Mark Achtemeier, "The Lordship of Jesus Christ" dalam A Passion for The Gospel: Confessing Jesus Christ for The $21^{s t}$ Century, Mark Achteimeier \& Andrew Purves, eds. (Lousville: Geneva Press, 2000), 15-29.
} 
keselamatan kita, kalau Allah telah menebus kita yang berdosa, mengapa kasih itu tidak nampak dalam keprihatinan kita sebagai manusia baru? Jadi keprihatinan ortodoksi parenial dan ortodoksi kontekstual menjadi sangat penting sekarang ini. Bagi Injili, konsep-konsep doktrinal penting, tetapi tidak berhenti sampai di sana, karena teologi bukan filsafat yang parenialisme saja. Telogi Injili berdasarkan penyataan Allah dan karya Kristus yang berinkarnasi. Jadi harus ada nilai praktis juga. Caranya dengan implementasi doktrin-doktrin yang teraplikasi dalam reartikulasi dan reformulasi. Jadi di sini teologi dalam doktrin Kristusnya harus terbuka pada refleksi konteks segar gereja-gereja agar dapat mengenal Yesus dalam pergumulan setempat.

Dengan demikan kaum Injili masih ada kesempatan untuk membuat teologi dalam konteks Asia secara wajar, bukan hanya ikut-ikutan demam teologi kontekstual dari non injili. Kaum Injili harus keluar melampaui gembar-gembor superiorisme Kristus tanpa buah pemikiran lanjutan yang baik untuk gereja di Asia. Teologi Injili akan mandul jika akademisinya tidak mau mengalami kemelekan intelekual dan tanpa buah pikiran yang mendalam. Belajar dari teologi reformed yang "tidak berhenti pada tatanan gereja, tetapi meluas satu sistem kehidupan dan tidak menghabiskan segenap energi dalam konstruksi dogmatis, tetapi menciptakan wawasan dunia dan hidup, serta dapat menyesuaikan dirinya bagi kebutuhan-kebutuhan setiap perkembangan manusia, dalam segala bidang kehidupan..." ${ }^{94}$ Di sini pendekatan akomodasi teologis dalam tradisi reformed tidak kaku dan mandeg dari situasi-situasi kemanusiaan sampai pada isu pembebasan sekalipun, dibanding golongan Injili lain. Dengan demikian di masa depan "Reformed tradition included deal with justice and liberation aesthical themes wich arise from theological reflection, They are items on their social witness agendas"; walaupun "they do not regard engagement in the strugel for justice and liberation as fundamental to ther dogmatic concern or theological method" yang penting di sini sudah ada jalan keluar secara agenda ke masa depan dan sekarang melanjutkan untuk" "the way in which such themes are reinterpreted from within the struggles for justice and liberation." ${ }^{\prime 65}$

\footnotetext{
${ }^{64}$ Abraham Kuyper, Ceramah-ceramah mengenai Calvinisme, terj (Surabaya: Momentum2005), 205.

${ }^{65}$ John de Gruchy, "Toward the Reformed Theology of Liberation" dalam Toward The Future of Reformed Theology: Tasks, Topics, Traditions, David Michael Welker, eds. (Grand rapids: Eerdmans, 1999), 107.
} 
Teologi Injili mengakui bahwa Yesus adalah Tuhan dan Juruselamat satu-satunya dan sangat menekankan keselamatan pribadi, dalam pemberitaan Injil rohani. Tetapi bagi kaum Injili sangat prihatin pada masalah sosial kemanusiaan sebagai implementasi doktrin. Berbeda dengan saudara lainnya yang konservatif, seperti Fundamentalis yang sangat anti sosial dan anti intelektual, sehingga berpikiran sempit dan picik tentang tugas dan doktrinnya. Tetapi kaum Injili juga tidak harus terjatuh pada sekularisme yang hanya mengasihani manusia berdasarkan humanisme semata-mata. Seperti halnya Kristus dalam Injil yang mengasihi orang banyak tanpa syarat, demikian juga tanpa harus menjadi liberal dulu kaum Injili dapat memperhatikan orang banyak.

Kita tidak menghindari kejuruselamatan-Nya dan mengganti dengan ketuhanan sebagai yang cocok, karena tidak mungkin ketuhanan-Nya tanpa kejuruselamatan-Nya. Singkatnya ketuhanan Yesus adalah masalah kehormatan dan kedudukan-Nya yang berhubungan dengan kematian dan kebangkitan serta hal-hal yang dilakukan Allah melalui Yesus. Namun juga yang tidak kalah adalah gelar itu menunjukan kekuasaan-Nya yang mutlak atas ciptaan dan segi iman dan kehidupan pengikut-Nya. ${ }^{66}$ Semuanya tidak menyentuh ketuhanan Yesus atas alam ciptaan, tetapi secara tidak langsung menyatakannya melalui pengikut-pengikut-Nya. Ketuhanan-Nya adalah meminta ketaatan kepada-Nya dalam kebaikan dan kebenaran, salah satunya adalah melalui pemeliharaan atas alam. Secara khusus memang bagi orang keselamatan, tetapi manusia ciptaannya tidak diabaikan dalam anugerah umum-Nya. Gereja Kristen harus menerima kenyataan itu dalam pengakuannnya akan Yesus adalah Tuhan (Lord). Yesus Kristus adalah Pencipta dan Pemelihara seluruh isi dunia. Yesus sebagai Penguasa dan Pemilik, "The lordship of Christ and the kingship of Christ in the political realis is the new theme that how shapes the nature of relationship between the kingdom of God and kingdom of this world. The lordship of Christ wants the manifest in goverments execution of office, as institutes 4.20 teaches: 'I peace (pax) freedom (libertas), justice (Iustitia)' ${ }^{67}$

\footnotetext{
${ }^{66}$ Guthrie, Teologi Perjanjian Baru 2, 338

${ }^{67}$ Hans -Joachim Kraus, "The Contemporary Relevance of Calvin" dalam Toward The Future of Reformed Theology, 324325.
} 


\section{Motif Inkarnasional Yesus dalam Keprihatinan Sosial.}

Pola inkarnasi Kristus adalah perendahan diri Kristus yang adalah Anak Allah yang mengambil rupa manusia, bahkan menderita sama seperti penderitaan kita. Inkarnasi Kristus adalah dasar untuk tindakan akomodasi teologis yang sering disalahmengerti oleh Injili yang berpendekatan ekstrim, serta menuduhnya sebagai relativisme dan secara sepintas menilai negatif motif dan cara akomodasi ini. Jalan pendekatan akomodasi dalam motif inkarnasi Kristus serta prinsip garam dan terang dunia adalah dasar prinsip akomodasi teologis untuk doktrin ketuhanan Yesus yang difokuskan pada pergumulan peradaban manusia, khususnya masalah perbudakan masakini. Saatnya untuk menguji lagi pendapat Injili yang selama ini menuduh seolah-olah pendekatan akomodasi tidak ada basis alkitabiahnya. Di sini akomodasi berarti persuasi dan toleransi dari kekristenan [yang kuat] kepada masyarakat [yang lemah]. ${ }^{68}$ Maka teologi Injili jangan lagi terlalu berpolemik dengan katoliksisme, liberalisme, sekularisme (dll.), dalam apa yang disebut unapologetical theology sebagai spirit kesatuan menghadapi permasalahan-permasalahan dunia, di dalam ketuhanan Yesus. Walau teologi Injili tidak bisa melepaskan secara keseluruhan tugas apologetisnya di dalam gerakannya, namun harus melampaui hal tersebut; sehingga dapat menghadapi realitas sesungguhnya dalam prinsip pemeliharaan Allah setelah keselamatan kristologis dalam relasi 'triadik' antara Tuhan, Manusia, dan dunia. ${ }^{69}$ Itu berdasarkan worldview alkitabiah tentang dunia dalam prinsip tiga seragkai 'antara ciptaan, kejatuhan dan penebusan' dan persepektif sejarah perjanjian penebusan kristologis antara Allah, dosa, dan keselamatan.

Yesus inkarnasi harus menuju pada gelar Yesus sebagai Tuhan pasca inkarnasi Kristus dan jabatanNya sebagai Raja yang ditinggalkan dalam gereja pada masa kini. Di sini makna transposisi dan akomodasi hampir sama dalam motif inkarnasi dalam kontekstualisas teologi Asia, hanya akomodasi Injili berprinsip adaptasi dan toleransi, sedangkan transposisi bermakna pindah tempat atau pindah waktu. Artinya prinsip

${ }^{68}$ Selengkapnya ada dalam tulisan saya, "Hakikat Akomodasi Teologis: Suatu Tinjauan Komprehensif" Stulos 4/1 (Juni 2006): 149-150.

${ }^{69}$ Lih. T.F Torrance, Reality and Evangelical Theology The Realism of Christian Revelation (Downers Grove: InterVarsity Press, 1982), xvi. 
transposisi berdasarkan makna eksistensial dan prinsip akomodasi bermakna spiritual dalam mengerjakan teologi di Asia. Di sinilah beda transposisi Song dan akomodasi yang saya usulkan. Keprihatinan sosial seharusnya bukanlah sekedar aksi baksos dari gereja-gereja lokal semata, tetapi suatu pemikiran mendalam dalam refleksi serius atas situasi dan kondisi riil dan aktual. Bukan sekedar sosial gospel dan Kristen sekularis yang profokatif, tetapi keniscayaan Kristen, sebagai murid Kristus.

Salah satu jabatan-jabatan Yesus adalah Nabi harus terkait dengan peran gereja dalam berita keadilan. Di sini Jabatan kenabian Yesus diambil alih dalam Tugas Kenabian Gereja. Ini tetap sejalan dengan jabatan Yesus sebagai Raja bagi umat-Nya dalam penebusan. Inilah dasar konsep lordship Yesus bagi dunia setelah kebangkitan-Nya. Jalan mediatornya adalah gereja atau keberadaan umat Tuhan masa kini. Ketuhanan Yesus melalui gereja ditinggalkannya berdasarkan jabatan-jabatan Kristus sebagai Raja, Imam, dan Nabi sekaligus. Khusus dalam kenabian, gereja menjalankan tugas sebagai pemberita peringatan dalam hal pergumulan situasional manusia seperti keadilan, kesejahteraan, kejahatan, dll., bagi dunia, setelah bagi dirinya sendiri. Namun Paulus lebih menunjukan pada ketuhanan Yesus secara universal terkait dengan ketuhanan secara pribadi. Kristus sebagai Penebus dan Pembebas dari perhambaan dosa. Dalam anugerah tidak ada diskriminasi hal-hal luar. Jadi anugerah Kristen harus menjadi dasar bagi tindakan belaskasihan Kristen. Kekepalaan Yesus atas gereja dan jabatan kenabian Yesus bagi dunia setara dengan tugas kenabian gereja bagi dunia yang menderita sekarang ini. Suara keadilan gereja adalah inti suara kenabian.

\section{Pentingnya Berita Ketuhanan Yesus dalam Tugas Kenabian Injili}

Selama ini kaum Injili pun mengakui memprihatinkannya permasalahan umat manusia. Pada abad 20 lalu, perbudakan pada masyarakat negara yang belum berkembang adalah contoh apa yang dikatakan “institutiolalized evil" dalam bentuk structural injustice pada masyarakat manusia. Sementara kaum Injili hanya memperhatikan "personalized evil."70 Ini sesuatu yang tidak berdampaknya teologi Injili pada masyarakat luas dan tidak berhasilnya melihat ketuhanan Yesus yang berdasarkan penebusan yang lebih besar, serta tidak celiknya teolog Injili di dalam menara gading akademis. Panggilan Gereja-gereja Asia

${ }^{70}$ Ronald J. Sider, 'God and Poor" dalam The Ministry of Development in Evangelical Perspective: A Symposium on the Social and Spiritual Mandate, Carl F. Henry, convenor and R.L Handcock (Pasadena: William Carrey Library, 1979), 37 
dalam tugasnya mengikrarkan Kristus dalam sistuasi Asia kontemporer. Jadi tidak boleh "dipahami sekedar teknik penginjilan dan kesaksian belaka," tetapi sebagai jalan untuk menemukan kekayaan Kristus yang lebih penuh, dalam rangka memperlakukan hal-hal yang akan datang. Jadi ada jalan untuk mengurusi keadaan hidup dari perspektif kristologi, khususnya fokus ketuhanan Yesus di dunia ini. Di sini penting melihat supremasi ketuhanan Yesus secara berpasangan dengan hakikat kenaikan Kristus dan inkarnasi Kristus.

Dari perspektif penciptaan, manusia, tanpa terkecuali dalam pangkat ras adalah milik Allah yang Maha Pengasih. Kristus mencipta dunia ini dan manusia pengusahanya, dalam konteks pemeliharaan atas semua hal di dunia, termasuk orang yang tidak percaya. Maka tidak layak orang mengatasnamakan ajaran Kristen untuk keabsahan perbudakan, baik pada masa lalu maupun sekarang (implisit dan eksplisit). Allah tidak memperbudak siapapun, walau ada klaim diri sebagai "Hamba Allah" dalam pelayanan Kristen. Apalagi Allah sudah membebaskan kita dari perbudakan dosa dengan penebusan Kristus di kayu salib, dan menjadikan kita dalam hubungan Anak dan Bapa dalam prinsip anugerah dari doktrin ketuhanan Yesus.

\section{Kesimpulan}

Berkristologi pada era ini adalah bagaimana menarik implikasi dan implementasi doktrin-doktrin kristologis untuk diartikulasikan kembali dalam prinsip-prinsip segar kehidupan nyata sehari-hari. Inilah suatu usaha berteologi kekinian, bukan sekedar mengulang pendapat-pendapat dari kutipan textbook saja, tetapi melampauinya tanpa harus merelatifkan ajaran ortodoksnya.

Di sinilah kristologi ketuhanan Yesus dijelaskan untuk masa kini, yaitu lebih menekankan Lordship disamping Lordness atau divinity-Nya. Keilahian-Nya sudah dipegang tetapi ketuhanan-Nya perlu diberitakan dan dihayati lebih lagi. Melalui kristologi, tema ketuhanan Yesus lebih menekankan keseimbangan yang proporsional, komprehensif, dan alkitabiah antara perspektif from above, from afore, juga from below. Artinya “mengenal karya Yesus harus melalui Pribadi dan Karya-Nya di dalam kebangkitan dan kenaikan- 
Nya sebagai Tuhan bagi Gereja dan atas dunia"; lalu menghormati ketuhanan-Nya secara praktis dalam kehidupan riil.

\section{Bibliografi}

Barna, George. Berpikir Seperti Yesus. Terj. Batam: Gospel Press, 2006.

Bloesch, Donald G. Jesus Christ: Savior and Lord. Downer Grove: InterVarsity, 1997.

Carl F. Henry, Convenor and R.L Handcock. Eds. The Ministry of Development in Evangelical Perspective: A Symposium on the Social and Spiritual Mandate. Pasadena: William Carrey Library, 1979.

Carter, Stephen L. The Culture of Disbelief: How American Law and Politics Trivilalize Religious Devotion. New York, London, etc: Anchor Books, Dobleday, 1993.

Choan-Seng Song, Yesus dan Pemerintahan Allah. Terj. Jakarta: BPK Gunung Mulia, 2010.

Crounch, Andy. Menciptakan Budaya: Menemukan Kembali Panggilan Kreatif Kita. Terj. Surabaya: Perkantas Jatim, 2011.

Fuller, Reginald H. The Formation of the Ressurection Naratives. Kentucky: Foretress Press, 1983.

Ham, W Stanley Money. What do you Say to a hungry world. Waco tx: Key Word book, 1975. 
Haseelgrave, David dan Edward Rommen. Kontekstualisasi: Makna, Metode dan Model. Terj. Jakarta: BPK Gunung Mulia, 1995.

Kuyper, Abraham. Ceramah-ceramah mengenai Calvinisme. Terj. Surabaya: Momentum: 2005. Iman Kristen dan Problem Sosial. Terj. Surabaya: Momentum. 2004.

McGrath, Alister. A Passion for Truth: Intelectual Coherence of Evangelicalism. Downer Grove: InterVarsity, 1996.

Mission Frontiers 29:4 (July -August 2007).

Nicholls, Bruce . The Unique Christ in Our pluralist World. Carlisle, Grand Rapids: Paternoster, Baker Books, 1994.

Platt, David. Radikal: Mengikut Yesus Berapa pun Harga yang Harus Dibayar. Terj. Surabaya: Perkantas Jatim, 2015.

Preston, Ronald H. Religion \& The Ambiguity of Capitalism. Claveland; The Pilgrim Press, 1993.

Rice, Spencer \& Chris. More Than Equal: Revised \& Expanded. Dwners grove: InterVarsity Press, 2000.

Ro. Bong Ring. Ed. The Bible and Theology: An Evangelical Theology on Asian Theology. Taichung: ATA, 1986. 
Siburian, Togardo. “Kemelekan Teologis dan Penulisan Injili”. Geneva: Jurnal Teologi dan Misi. Vol. 1 No 1 (Agustus 2011): 133-154.

Stott. John. Isu-isu Global Menantang Kepemimpinan Kristen, terj. Jakarta: OMF/YKBKB, 1992.

Torrance, T.F. Reality and Evangelical Theology The Realism of Christian Revelation. Downers Grove: InterVarsity Press, 1982.

Vinay Samuel dan Chris Sugden, eds., Sharing Jesus in Two Third: Evangelical Christology from Context of Poverty Powerless and Religious Pluralism. Grand Rapids: Wm Eerdmans Pub. 1883.

Webber, Robbert E. Younger Evangelicals Facing The Challenge of the New Wolrld. Grand Rapids: Baker, 2002.

Welker, David Michael. Eds. Toward The Future of Reformed Theology: Tasks, Topics, Traditions. Grand Rapids: Eerdmans, 1999.

Wright, Chris. Tuhan Yesus Memang Khas Unik: Jalan Keselamatan Satu-Satunya. Terj. Jakarta: YKBK/OMF, 2003. 